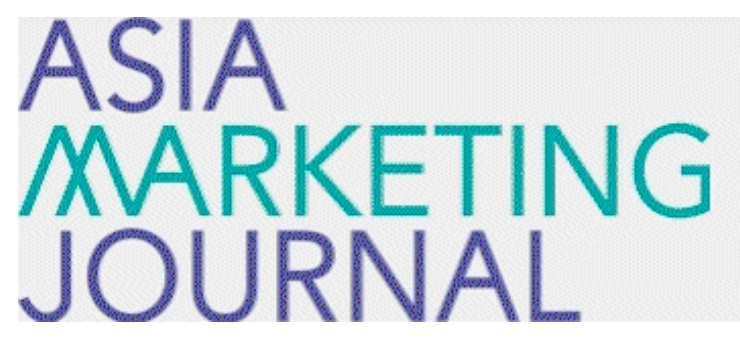

ASIA MARKETING JOURNAL

Volume 9 | Issue 1

Article 3

4-30-2007

\title{
산업재 브랜드 자산의 구성요인들이 관계적 성과에 미치는 영향에 관한 연구
}

Sang Lin Han

Hyung Suk Sung

Follow this and additional works at: https://amj.kma.re.kr/journal

Part of the Marketing Commons

\section{Recommended Citation}

Han, Sang Lin and Sung, Hyung Suk (2007) "산업재 브랜드 자산의 구성요인들이 관계적 성과에 미치는 영 향에 관한 연 구," Asia Marketing Journal: Vol. 9 : Iss. 1 , Article 3.

Available at: https://doi.org/10.53728/2765-6500.1189

This Article is brought to you for free and open access by Asia Marketing Journal. It has been accepted for inclusion in Asia Marketing Journal by an authorized editor of Asia Marketing Journal. 


\section{산업재 브랜드 자산의 구성요인들이 관계적 성과에 미치는 영향에 관한 연구}

\section{A Study on Industrial Brand Equity Affecting the Relational Performance between Industrial Buyers and Suppliers}

한 상 린(Han, Sang-Lin)*

성 형 석(Sung, Hyung-Suk)**

본 연구는 브랜드자산 구성오소에 대한 기존 문헌의 고찰을 통해 그동안 그 중요성에도 불구하고 산업재 시장에서는 거의 다루어지지 않고 있는 브랜드 자산형성 요인의 일반적 구성모델을 제시하고 있다. 구조방정식모델을 통해 브랜드 태도형성 요인인 브랜드 인지/연상, 브랜드 지각가치, 서비스 품 질과 브랜드 행동형성 요인인 브랜드 전환비용, 브랜드 관계만족, 브랜드 커뮤니티가 브랜드 충성도 및 관계몰입과 기업성과 및 구매자가치에 미치는 영향을 분석하였다.

기업성과 및 구매가치에 영향을 미치는 8가지의 브랜드 자산요인들에 초점을 두고 있다. 실증분석 은 산업재 구매자를 대상으로 설문조사하였는데 구조방정식에 의한 모델분석 결과, 브랜드에 대한 태 도를 형성하는 요인인 브랜드 인지/연상, 브랜드 지각가치, 서비스 품질은 브랜드 충성도에 유의한 영향을 미치는 것으로 나타났으며 브랜드에 대한 행동을 형성하는 요인인 브랜드 전환비용, 브랜드 관계만족 또한 브랜드 충성도에 유의한 영향을 미치는 것으로 나타났다. 그리고 각 형향요인들의 브 랜드 충성도에 영향력을 파악해 보았을 때 주요 영향요인들은 브랜드에 대한 태도를 형성하는 요인 들 보다는 브랜드에 대한 행동을 형성하는 요인들인 것으로 나타났다. 이와 더불어 브랜드 충성도가 클수록 공급자-조직구매자 간의 관계몰입과 기업성과 및 구매가치가 더 높은 것으로. 나타났으며 관 계몰입은 브랜드 충성도와 구매가치, 기업성과에 중요한 매개적인 역할을 하는 것으로 나타났다.

핵심개념: 산업재 브랜드, 브랜드 충성도, 관계적 성과

\footnotetext{
* 한양대학교 경영대학 교수(sihan@hanyang.ac.kr)
}

** 한양대학교 경영대학 강사(sunghs@freechal.com) 


\section{I. 서 론}

지난 수십년 동안 소비재 마케팅에서는 전통 적으로 브랜드의 중요성을 매우 강조해 왔으나 산업재 마케팅 분야에서는 제품의 특성상 브랜 드에 대해서는 관심을 보이지 않았다고 할 수 있다. 그러나 최근 들어 산업재 시장에서도 브 랜드에 대한 관심이 증가하고 있으며 인텔의 Intel Inside 광고, AMD 반도체사의 애슬론 64, 삼성 SDI의 와이즈뷰, LS산전의 Susol 등은 좋 은 예라고 할 수 있다.

그동안 산업재 마케팅 분야에서 많이 연구가 이루어진 조직구매자-공급자의 장기적인 교환 관계의 형성요인들 중에서 그 중요한 역할에도 불구하고 상대적으로 연구가 거의 이루어지지 않고 있는 분야가 산업재 시장에서의 브랜드 자산에 관한 연구라고 할 수 있다. 서로간의 장 기적인 관계형성이 산업재 사업성과의 실패를 좌우한다고 보았을 때 서로간의 관계적 몰입과 신뢰가 바탕이 되어야 하는데 여기에서 브랜드 자산은 구매자의 만족을 통한 브랜드에 대한 충성도, 브랜드 전환비용, 그리고 브랜드 지각 품질, 등을 증가시켜 관계적 몰입을 유도할 수 있다. 그동안 산업재 시장에서 브랜드 자산의 효과가 존재하는가에 대한 탐색적 연구 및 실 증 연구는 몇 차례 시도된 적이 있으며 실제로 이들 연구에서 브랜드 자산은 구매자와의 관계 에서 매우 중요한 역할을 하는 것으로 나타났 다(Anderson 2004; Bendixen, Bukasa, and Abratt 2004; Low and Blois 2002). 이러한 브 랜드 자산의 효과는 산업재 시장과 같은 장기 적인 신뢰와 몰입을 요구하는 시장특성 내에서
더욱 더 그 영향력이 크다고 할 수 있다. 지금 까지의 연구결과에 의하면 구매자와 장기적 관 계를 형성하고 있는 공급자는 그렇지 않은 공 급자에 비해 매출 성장율은 높고 재고보유 및 통제비용은 낮으며 수익성은 높은 것으로 나타 나고 있는데(Kalwani and Narayandas 1995) 이는 소비재 시장과 마찬가지로 산업재 시장에 서도 브랜드 자산은 조직구매자-공급자의 장기 적 거래관계에 영향을 주는 중요한 요인이라고 볼 수 있다.

본 연구는 그동안 몇몇 연구자에 의해 간헐적 으로 시도되었던 산업재 시장 내에서의 브랜드 가치의 영향력에 대한 탐색적 연구에서 벗어나 브랜드자산 구성요소에 대한 구조적 관계에 대 해서 산업재 시장을 중심으로 브랜드 자산형성 오인의 일반적 구성모델을 제시하고 있으며 구 조방정식모델을 통해 브랜드에 대한 태도를 형 성하는 요인들(브랜드 인지/연상, 브랜드 고객 가치, 서비스 품질) 과 브랜드에 대한 행동을 형성 하는 요인들(전환비용, 관계만족, 브랜드 커뮤니 티)이 브랜드 충성도와 관계몰입, 그리고 기업성 과 및 구매가치에 미치는 영향을 실증분석하였다. 지금까지 산업재 시장에서 브랜드 자산 혹은 가치에 관한 연구는 주로 부분적으로 진행되어 왔기 때문에 통합적이고 전체적인 구성모델을 연구할 필요성은 계속해서 언급되어왔다. 그동 안 산업재 시장에서는 조직구매자와 공급자간 의 거래관계에서의 장기적인 영향요인들과 이 들 관계에 영향을 미치는 주요변수들에 관한 연구가 주된 관심사였다(Doney and Cannon 1997; Ganesan 1994: Kalwani and Narayandas 1995; 한상린 1998). 이러한 장기적인 거래관계 에 대한 연구와 더볼어 최근 소비재 시장과 마 
찬가지로 산업재 시장에서도 구매자의 중오한 선택의 기준이 듸는 브랜드 자산에 영향을 미 치는 오인들에 대한 구조적 관계나 변수들의 관련성에 대한 연구는 매우 중요하다고 볼 수 있다. 더욱이, 공급자에 대한 조직구매자의 행 동모델이 여러 개의 경쟁 브랜드들 중에서 어 떤 선택을 하느냐의 문제라고 보았을 때 그 중 요성이 크기 때문에 이에 대한 연구노력이 이 루어져야한다고 볼 수 있다. 이에 본 연구는 산 업재 시장에서 공급자 브랜드에 대한 자산을 형성하는 요인들이 관계몰입 및 기업성과, 구매 가치에 어떠한 영향을 미치는가에 연구의 초점 을 두고 진행하였다.

\section{II. 연구가설과 연구모형의 설정}

\section{1 브랜드 인지/연상}

브랜드 자산(brand equity)은 가장 일반적으 로 강력한 브랜드에 대한 연상과 브랜드 인지 수준, 지각된 품질, 그리고 브랜드에 대한 애호 도로 판단할 수 있다(Yoo et al. 2000)。즉 기존 마케팅 관점에서 브랜드 자산에 대한 연구는 브랜드에 대한 지각된 품질, 인지/연상, 애호도 가 브랜드 선텍의 확률, 만족도, 가격 프리미엄 을 제공한다고 하였다. 또한, 경쟁적 마케팅 행 동에 대한 약점과 가격상승에 대한 탄력적 응 답을 감소하며 마케팅 커뮤니케이션의 효과성 과 브랜드 라이센싱 기회를 증가시키며 경쟁 우위 등과 같은 기업성과에 긍정적 영향을 준 다(Keller, Susan, and Houston 1998)고 하였다.
브랜드 자산의 구성요인 중에서 인지수준과 함께 연상(association)이라는 요소는 제품군과 브랜드에 따라 독특한 이미지를 연상시키기 때문 에 중요한 요소라고 할 수 있다. Aaker(1996) 는 연상 내용의 측정을 브랜드 아이덴티티 (brand identity)의 세 가지 관점을 사용하여 구성할 수 있다고 언급하였고 이러한 개넘은 기존 연구들(Krishenan 1996; Yoo et al. 2000) 에서 적용되어왔다. 그리고 $\mathrm{YoO}$ et al.(2000)은 브랜드 인지(brand awareness)와 브랜드 연상 (brand association)의 개념을 독립적인 개념이 아닌 하나의 개념으로 언급하고 있다. Aaker (1996)와 Keller et al.(1998)는 브랜드 인지도 는 브랜드에 대한 충성도를 구성하는 가장 기 본이 되는 오소이자 중요한 개념이라고 하였다. 따라서 본 연구에서는 공급자 브랜드에 대한 인지도를 인지와 연상의 수준으로 보았으며 이 러한 인지/연상이 높을수록 산업재 브랜드에 대한 충성도는 높아질 것으로 가정하였다.

H1(a): 산업재 시장에서 브랜드에 대한 인 지/연상은 브랜드 충성도에 직접적 인 정 $(+)$ 의 영향을 미칠 것이다.

\section{2 지각된 가치}

산업재 시장에서 조직구매자의 지각된 가치가 공급자 브랜드에 대한 충성도에 정 $(t)$ 의 영향 을 미친다는 가설은 이와 관련한 Jacoby(1971) 과 Jacoby and Chestnut(1978)의 초기의 연구 에서 주장한 바와 같다. 이 연구에서는 생명보 험 서비스를 구매할 때 구매자의 재정적 위험 은 구매자의 지각된 위험과 같은 것으로 나타 
났다. 비록 Jacoby(1971)의 연구에서 사용되었 던 개넘보다는 넓은 개넘이지만 최근의 연구 에서도 지각된 가치는 브랜드 충성도와 인과 적 관련성이 매우 높은 것으로 간주되어진다 (Sinha and DeSarbo 1998).

톡히 Erdem and Swait(1998)은 구매자의 브 랜드에 대한 지각된 가치가 클수록 특정 브랜 드를 지속적이고 반복적으로 구매하려는 경향 이 커진다고 하였다. 따라서 브랜드에 대한 지 각된 가치와 브랜드에 대한 충성도는 인과적 관계가 있다고 볼 수 있다. 그리고 이러한 직접 적인 영향관계는 산업재 시장에서 조직구매자 가 공급자의 브랜드에 대한 지각된 가치가 높 다고 인식할수록 공급자 브랜드에 대한 충성도. 가 높아지는 것으로 판단할 수 있다.

$\mathrm{H} 1(\mathrm{~b})$ : 산업재 시장에서 브랜드에 대한 지 각된 가치는 브랜드 충성도에 직접 적인 정(+)의 영향을 미칠 것이다.

\section{3 지각된 서비스 품질}

일반적으로 산업재 거래에서는 우수한 품질 의 제품과 함께 정확한 납기와 유지보수 등 서 비스의 중오성이 오래전부터 매우 강조되어 왔 다. 거래특위(transaction-specific) 측면에서는 서비스 품질과 만족간의 관계가 명확하게 연관 성을 갖고 있지는 않는 것으로 나타났지만 (Parasuraman, Zeitheml, Berry 1994a; Taylor, Celuch, and Goodwin 2004), 일부 다른 연구에 서는 지각된 서비스 품질은 비교적 안정적인 구매자 지각으로 간주되어지며 구매자의 구매 경험을 통한 만족과 불만족에 영향을 미치는
것으로 나타났다(Bejou, Wray, and Ingram 1996), 즉, 공급자 브랜드에 대한 조직구매자의 지각된 서비스 품질이 높아질수록 공급자 브랜 드에 대한 만족을 통해 브랜드 충성도를 높이 게 된다고 볼 수 있다.

공급자와 구매자의 거래에서, 구매자는 서비 스를 올바르게 제공하는지와 만약 잘못 제공되 어졌을 때 이를 배로 잡는지를 평가하게 된다. 또한 구매자는 얼마나 잘 자신의 요구사항을 들어주는지와 얼마나 잘 공급자의 자발적인 행 동과 태도를 보여주는지도 평가한다. 서비스가 구매자가 기대하는 수준과 일치하게 되면 구매 자는 공정하고 이성적으로 자신이 대우받았다 고 평가하게 된다. 즉, 구매자의 신뢰성, 반응 성, 확신성, 그리고 제품 및 서비스 납기 프로 세스의 공감이 커지면 커질수록 구매자는 더욱 공정하고 공평하게 자신이 대우받고 있다고 생 각할 수 있다. 지각된 서비스 품질과 지각된 자 산의 관계는 Wells and Stafford(1995)에 의해 연구되어졌는데 그들은 자동차 보험에서 구매 자가 느끼는 서비스 품질이 높을수록 구매자 불평은 더욱더 낮아진다고 제시하였다. 이에 본 연구에서는 브랜드에 대한 지각된 서비스 품질 이 높을수록 구매자의 브랜드에 대한 충성도는 높아 질 것으로 가점하였다.

$\mathrm{H} 1(\mathrm{c})$ : 산업재 시장에서 지각된 서비스 품 질은 브랜드 충성도에 직접적인 정 $(+)$ 의 영향을 미칠 것이다.

\section{4 전환비용}

마케팅 분야에서 재구매 의도에 대해 전환비 
용이 가지는 영향력에 대한 연구들은 구매자 만족과 더불어 재구매 결정으로 전환비용을 제 시하고 있으며 구매자 이탈의 방지책으로 강조 하고 있다(Fornell, Johnson, Anderson, Cha, and Bryant 1996; Heskett, Jones, Loveman, Sasser, and Schlesinger 1994). 전환비용은 구 매자가 타사의 경쟁 브랜드를 선택함으로 인해 발생하는 비용이다(Gronhaug and Gilly 1991).

전환비용이 증가할수록 구매자는 타사의 브 랜드로 전환하기가 더욱더 어려워진다(Jones, Mothersbaugh, and Beatty 2000; Sharma and Patterson 2000). 따라서 각 공급자들은 자사의 브랜드 전환비용을 높이기 위한 마케팅 전략을 다각도로 모색해야 한다(Fornell et al. 1996). 이를 통해 보았을 때 브랜드에 대한 전환장벽 은 브랜드에 대한 충성도를 높이기 위해 사전 적으로 매우 중요한 의미를 갖는다고 볼 수 있 다. 따라서 본 연구는 산업재 시장에서도 전환 비용이 클수록, 조직구매자가 다른 공급자의 브 랜드로의 전환이 어렵고 자사의 브랜드에 대한 충성도를 더 갆하게 가질 것으로 보았다. 물론, 전환장벽과 브랜드 충성도 간의 인과적 관계에 있어서 매개적 역할을 하는 다른 영향요인이 존재할 수 있는 가능성을 배제할 수는 없지만 본 연구는 전환장벽을 브랜드 지각품질과 더불 어 브랜드 충성도에 영향을 미치는 행동적 구 성개념으로 파악하여 직접적인 영향을 미칠 것 으로 가정하였다.

$\mathrm{H} 2(\mathrm{a})$ : 산업재 시장에서 브랜드 전환비용은 브랜드 충성도에 직접적인 정 $(+)$ 의 영향을 미칠 것이다.

\section{5 관계만족}

브랜드에 대한 관계만족은 태도적 변화(선호 도, 애호도 등)에 영항을 미치며 이것은 다시 재구매 의도에 영향을 미친다. 높은 수준의 만족 은 브랜드가 구매자의 고려상표군(consideration set)에 들어갈 가능성을 높여주고 구매자의 브 랜드에 대한 애호도를 높여준다. 구매자와의 관 계는 구매자와 대면 시 한 번에 하나의 상호작 용이 이루어진다고 볼 수 있다. 특히, 산업재 시장에서 반복적인 조직구매자와의 긍정적인 대면은 구매자 만족, 신뢰, 관계몰입 그리고 장 기적 관계의 지속성을 증가시킨다(Morgan and Hunt 1994; Selnes 1998). 이와 더불어 관계만 족과 재구매 행동 사이의 긍정적인 관계는 기 존 연구에서 언급되어져 왔다(Andreassen and Lindestad 1998; Srinivasan 1996). 일반적으로 구매자는 다양한 긍정적 혹은 부정적 결속들에 의해 영향을 받는다. 부정적 결속(구매자 관성, 브랜드 프로모션, 구매자 정보처리의 제약, 공 급자 독점)은 구매자만족이 불충분할지라도 특 정 공급자에 강하게 결속시켸주는 역할을 한다. 구매자의 불만족은 전환비용, 관계만족, 구매 자 몰입, 그리고 브랜드 충성도에 부정적 영향 을 미친다(Mittal, Ross, and Baldasare 1998). Bloemer and de Ruyter(1998)는 만족과 충성 도의 관계는 구매자가 브랜드 기대-성과의 비 교를 어떻게 받아들이느냐에 따라 그 영향이 달라질 수 있다고 제시하였다. 따라서 조직구매 자의 전체적인 브랜드 만족이 공급자 브랜드 충성도에 정 $(+)$ 의 유의한 영향을 미친다는 가 정을 하였다. 
$\mathrm{H} 2$ (b) : 산업재 시장에서 브랜드 관계만족은 브랜드 충성도에 직접적인 정 $(+)$ 의 영향을 미칠 것이다.

\section{6 브랜드 커뮤니티}

특정 브랜드에 대한 커뮤니티는 공유할 수 있 는 활동, 목표, 관계 등이 동일한 브랜드를 소 유하는 다른 사람들과의 관계에서 이루어지며 제품에 대한 컨셉 혹은 서로간의 정보나 지원 등을 공유함으로써 생겨난다. 이러한 브랜드 커 뮤니티는 특정 브랜드에 대한 소비를 중심으로 하는 하위문화를 형성하게 되었다(Schouten and McAlexander 1996). 구매자들의 관점에서 는 보다 중요한 정보원천을 제공하며, 구매자들 간의 상호작용을 통하여 보다 광범위한 사회적 혜택, 심지어 감성적 혜택과 이에 따르는 유대 감까지도 제공하는 역할을 하는 것으로 이해되 고 있다(Muniz and O'Guinn 2001). 이는 브랜 드와 구매자와의 관계뿐 아니라, 구매자와 구매 자 간의 상호관계를 나타내는 삼각형의 모형으 로 설명될 수 있다(Muniz and O'Guinn 2001). 브랜드 커뮤니티에 대한 기존 연구들은 Aaker (1996)가 브랜드 자산의 네 가지 구성요 소로 지적한 지각된 품질, 브랜드 충성도, 브랜 드 인지도, 브랜드 연상에 모두 직접적인 영향 을 주며, 브랜드 충성도와 마찬가지로 브랜드 자산에 영향을 미치는 중요한 변수가 된다고 하였다(Keller et al. 1998; Muniz and O'Guinn 2001). 이에 본 연구는 공급자와 조직구매자 간 의 브랜드 커뮤니티가 공급자 브랜드 충성도에 직접적인 정 $(+)$ 의 영향을 미칠 것으로 가정하 였다.
$\mathrm{H} 2(\mathrm{c})$ : 산덥재 시장에서 브랜드 커뮤니티의 활성화는 브랜드 충성도에 직접적인 정 $(+)$ 의 영향을 미칠 것이다.

\section{7 브랜드 충성도}

Oliver(1993)는 브랜드 충성도를 미래에도 일 관되게 선호하는 제품을 구매하고 소중하게 생 각하는 몰입(commitment)으로서 가슴 깊숙이 갖고 있으며, 이에 반하는 마케팅 노력이나 상 황적 영향에도 불구하고 동일한 브랜드나 동일 한 브랜드군을 반복적으로 구매하게 하는 것이 라고 정의하였다. 이러한 정의의 이면에는 행동 적, 태도적 요소를 모두 포함하고 있다. 행동적, 태도적이라는 개념여 대한 연구(Aaker 1996: Oliver 1993)에서 기술된 바 있는 브랜드 충성 도는 상이한 두 가지 측면을 강조한 것이다. 이 러한 연구결과들은 브랜드 충성도가 존재하기 위해서는 행동적, 태도적 충성도가 동반하여야 한다는 점을 의미하는 겟이다.

브랜드에 대하여 충성도를 보이는 구매자는 충성적이지 못한 구때자나 전환 구매자에 비해 브랜드에 대하여 더 호의적인 반응을 나타낸다 (Grover and Srinivasan 1992). 행동적 충성도 와 태도적 충성도의 비쭝차이는 알 수 없으나 행동적, 태도적 충성도는 브랜드 자산의 증가와 관련되어 있다고 볼 수 있다. 가격 프리미엄과 시장 점유율은 점증하는 대표적인 브랜드 자산 개념과 밀접하게 연관되어 있다(Aaker 1996). 구매의도에 대한 브랜드 충성도의 효과는 기존 연구에서 드물게 연구되어져 왔는데 구매자의 선택과 관련한 행동이론에 관한 연구는 Kardes, Kalyanaram, Chandrashekaran, and Dornoff 
(1993), Roberts and Lattin(1997), 그리고 Shocker et al.(1991)의 고려상표군에 의해 보 다 많이 논의되었다. 그리고 Erdem and Swait (1998)은 구매자 충성도 및 재구매에 관한 구 조적 모델을 제시하였다. 이러한 기존 연구를 바탕으로 본 연구는 특정 공급업자의 브랜드 충성도는 조직구매자와 공급자 간의 관계몰입 에 영향을 미친다는 가정을 하였다.

$\mathrm{H} 3$ : 산업재 시장에서 브랜드 충성도는 관계 몰입에 직접적인 정 $(+)$ 의 영향을 미칠 것이다.

\section{8 관계몰입}

과거에 산업재 시장에서 조직구매자-공급자 관계가 밀접해지고 장기화되는 현상을 주도한 것은 주로 구매자 쪽이었으며 이를 통해 구매 자들은 장기 거뢔관계에 의한 유리한 점을 언 을 수 있었다. 그 후 공급자 측면에서도 긍정적 인 혜택을 볼 수 있다는 것을 보여주는 연구들 이 등장했으며(Kalwani and Narayandas 1995) 한상린(2003)의 연구에서는 매출 안정성, 마케 팅 효율성 증가, 최적 생산계획 등 장기관계에 따른 좋은 점들이 나타나고 있어 구매자와 공 급자 모두 장기거래 관계에 의한 혜택을 볼 수 있을 실증적으로 보여주고 있다. 또한 한상린 $(1998,2003)$ 은 기업 간 거래 시 관계몰입의 수 준이 높을수록 기업성과는 높아진다고 하였으 며 이에 본 연구에서도 관계몰입이 높으면 기 업성과가 높아지는 것으로 가정하였다.

$\mathrm{H} 4(\mathrm{a})$ : 산업재 시장에서 관계몰입은 기업성
과에 직접적인 정 $(+)$ 의 영향을 미칠 것이다.

본 연구에서 브랜드 충성도란 여러 제품 중 특정 제품의 브랜드를 의미하고 관계몰입이란 그 거래처와의 전반적인 거래관계의 장기지향 성을 의미한다고 볼 수 있다. 그동안 마케팅 분 야의 문헌들에서 지각된 가치가 고객만족, 구매 의도 및 재구매 의도에 유의한 영향을 미친다 는 연구결과는 많은 학자들에 의해 이론연구, 사례연구. 그리고 실증연구을 통해 제시되어왔 다(Anderson 2004). 가치에 대한 정의는 다양 한 형태 및 분야에서 제시되고 있는데 본 연구 에서는 Cronin, Brady, and Hult(2000)의 연구 에 기초하여 구매가치를 편익과 비용 간 상쇄 에 의해 구매자가 지각하는 가치에 대한 전반 적인 평가로 정의하였으며 기존의 고객가치에 기초하여 본 연구의 변수인 구매가치를 제시한 경제적 가치와 경험적 가치에서 오는 우수성 및 편리성, 효율성의 3 가지 차원으로 구성된다 고 보았다.

그러나 본 연구에서는 기존의 소비자 연구들 이 고객가치 및 고객만족은 재구매 의도를 높 여준다는 주장(Anderson and Narus 1990) 과는 달리 산업재 시장에서는 조직구매자와 공급자 간의 거래에서 관계적 몰입이 높아질수록 조직 구매자가 인식하는 구매가치는 더욱 높아질 것 으로 가정하였다.

$\mathrm{H} 4(\mathrm{~b})$ : 산업재 시장에서 관계몰입은 구매가 치에 직접적인 정 $(+)$ 의 영향을 미칠 것이다. 


\section{III. 연구설계 및 실증분석}

\section{1 연구변수의 조작적 정의}

본 연구의 구성요인들의 측정항목은 아래와 같이 기존 문헌을 활용하였으며 각 요인들에 대한 조작적 정의 및 세부 측정항목은 다음과 같다. 본 연구의 연구모델에서 제시하고 있는 구성요인들은 총 10 개이며 요인들에 대한 세부 측정항목은 아래의 기존문헌을 참고하였으며 측정법은 리커트 7점 척도를 이용하였다. 각 변 수에 대한 세부적 측정항목은 다음과 같다.

브랜드 인지/연상은 브랜드에 대해서 연상되 는 제품의 속성, 느낌, 그리고 인지수준을 의미 하며 세부적 측정항목은 다음과 같이 구성되었 다. 위의 브랜드를 보면 제품의 성격을 알 수 있다. 위의 브랜드를 보면 공급자의 기술 수준 을 알 수 있다, 위의 브랜드를 보면 공급자의 명성을 알 수 있다, 위의 브랜드를 보면 공급자 를 신뢰를 알 수 있다, 위의 브랜드를 보면 공 급자의 능력을 알 수 있다, 위의 브랜드를 보면 긍정적인 느낌을 준다, 위의 브랜드를 보면 제 품을 누가 사용하는지 쉽게 생각난다, 위에서 적어주신 "OOO) 브랜드" 에 대하여 매우 질 알고 있다. 지각된 품질은 거래하고 있는 공급 자의 제품 및 서비스에 대한 납기 프로세스의 전체적인 평가를 의미한다. 세부적 측정항목은 다음과 같이 구성되었다. 공급자의 종업원은 자 신들의 제품 및 서비스가 언제 정확하게 제공 되는지에 대해서 말해준다, 공급자의 종업원은 우리에게 제품 및 서비스를 신속하게 전달한다, 공급자의 종업원 행동은 우리에게 확신을 심어
준다, 공급자 종업원은 우리의 정확한 욕구를 이해한다. 지각된 가치는 거래하고 있는 공급자 의 제품 및 서비스에 대해 느끼는 전체적인 가 치평가를 의한다. 세부적 측정항목은 다음과 같 이 구성하였다. 공급자의 브랜드는 타사와 비교 했을 때 프리미엄 가격(더 비싼 가격)을 지불 하고서라도 구매할 만한 가치가 있다, 공급자의 브랜드의 유연성은 우리의 옥구를 충분히 채워 주고 있다, 공급자의 브랜드는 우리에게 추가적 인 혜택과 지원을 제공한다, 우리는 공급자가 제공하는 제품 및 서비스에 대해 정확하게 이 해하고 있다, 우리는 공급자의 브랜드에 대한 가격이 적정한 수른이라고 생각한다, 우리는 공 급자의 브랜드를 구매하는 것이 좋은 결정이었 다고 생각한다.

관계만족은 거래하고 있는 공급자의 제품 및 서비스에 대해 느끼는 전체적인 만족 및 즐거 움을 의미한다. 세부적 측정항목은 다음과 같이 구성하였다. 우리와 공급자와의 구매결정은 현 명한 선택이었다, 우리는 공급자와의 구매결정 에 만족을 느낀다, 우리는 공급자와의 구매결정 을 하게 즐겁다, 우리는 공급자의 제품 및 서비 스를 추천할 수 있다. 브랜드 전환비용은 거래 하고 있는 공급자의 브랜드에서 다른 공급자의 브랜드로의 전환 시 소요되는 시간, 노력, 비용 에 대한 손실의 정도를 의미한다. 세부적 측정 항목은 다음과 같이 구성하였다. 현재의 공급자 에서 타사의 브랜드로 구입전환 시 소요되는 비용에 대한 부담이 매우 크다. 현재의 공급자 에서 타사의 브랜드로 구입전환 시 느끼는 불 편함이 매우 크다, 현재의 공급자에서 타사의 브랜드로 구입전환 시 소오되는 시간에 대한 부담이 매우 크다, 현재의 공급자에서 타사의 
브랜드로 구입전환 시 많은 비용이 들 것이다. 브랜드 커뮤니티는 거래하고 있는 공급자의 브 랜드 커뮤니티 수준을 의미한다. 세부적인 측정 항목은 다음과 같이 구성하였다. 공급자와 온라 인 혹은 오프라인 상에서 업무시간 외에 자주 만나 정보를 주고받는다, 공급자와의 커뮤니티 를 통해 우리의 의사를 반영할 수 있는 기회가 많다, 커뮤니티를 통해 정보공유 뿐만 아니라 필요한 욕구롤 적절히 충족시키고 있다, 커뮤니 티를 통해 정서적인 친밀감을 느끼며 친하게 지낸다, 주변 사람들에게 이 커뮤니티를 홍보하 거나 참여를 권유한다, 앞으로 지속적으로 이 커뮤니티를 계속 이용할 생각이다. 브랜드 충성 도는 거래하고 있는 공급자의 브랜드를 지속적, 반복적 구매를 하는 정도를 의미한다. 세부적 측정항목은 다음과 같이 구성하였다. 다음번에 구매한다면 이 브랜드를 구매할 것이다, 우리는 이 브랜드를 계속하여 구매하려한다, 우리는 의 브랜드를 지속적으로 열망한다, 다른 브랜드에 비해 이 브랜드에 보다 높은 가격을 기껴이 지 불할 것이다.

기업성과는 공급자와의 거래를 통해 창출된 성과를 의미한다. 세부적 축정항목은 다음과 같 이 구성하였다. 이 공급업체와의 관계로 인해서 거래 시 발생되는 협상비용, 정보수집 비용, 내 부 업무처리 비용 등이 절감되었다, 이 공급업 체와의 관계로 인해서 주문 및 재고유지 비용 이 절감되었다. 이 공급업체와의 관계로 인해서 시세보다 낮은 가격으로 제품을 공급을 받고 있다. 이 공급업체와의 거래관계는 당사의 매출 성장에 어느 정도 기여하고 있다. 만약 이 공급 업체와 거래를 하지 않는다면 우리의 전체 매 출은 어느 정도 타격을 받을 것이다, 만약 이
공급업체와 거래를 하지 않는다면 당사의 전체 이익은 어느 정도 감소할 것이다, 이 공급업체 는 제품 주문 시 신속하게 배달한다, 이 공급업 체는 주문 시 제품 납기일을 정확히 지킨다. 관 계몰입은 거래하고 있는 공급자와의 지속적인 거래 욕구 및 긴밀한 관계유지 의도를 의미한 다. 세부적 측정항목은 다음과 같이 구성하였 다. 우리는 공급자와 앞으로 지속적으로 거래를 하고픈 옥구가 생긴다, 우리는 앞으로 공급자와 긴밀한 관계유지를 할 의향이 있다, 우리는 공 급자와 앞으로 지속적인 거래에 따른 손실을 감수할 수 있다, 우리는 공급자와 거래를 증진 시키기 위한 투자를 할 의향이 있다. 구매가치 는 공급자와의 거래를 통한 얻는 구매가치를 의미한다. 세부적인 측정항목은 다음과 같이 구 성하였다. 제품 및 서비스 수준을 감안하면 가 격은 적당한 편이다, 가격에 비해 매우 우수한 제품 및 서비스를 제공한다, 지불하는 가격 이 상의 우수한 가치를 제공한다, 뛰어난 전문적인 지식과 기술을 가지고 있다, 우리에게 믿을 수 있는 제품 및 서비스를 제공한다, 우리의 욕구 를 매우 잘 이해한다.

\section{2 표본설계}

설정된 연구가설을 검증하기 위해 전통적으로 가장 대표적인 산업재라 할 수 있는 기계, 전 기, 전자산업 등의 분야에서 구매 담당자들을 표본 프레임으로 하여 무작위 샘플조사를 실시 하였다. 조사대상은 $\mathrm{B} 2 \mathrm{~B}$ 시장에서의 구매자-공 급자의 관계에 있는 구매자를 대상으로 하였으 며 조사원에 의한 직접 면접과 우편조사를 병 행한 결과 총 230 부의 설문지를 회수하여 총 
212부를 분석에 사용하였다.

설문지는 산업재 시장 내에서 부품 및 원재로 를 구매하는 조직구매자를 대상으로 진행되었 으며 응답자들은 하나의 중요한 공급관계를 선 택하도록 하였으며 거래기간이 2년 미만의 조 직구매자는 제외시켰다. 이와 더불어 변수들에 대한 측정에 앞서 거래하고 있는 공급자의 브 랜드명을 조직구매자가 설문에 앞서서 빈칸에 정확하게 적도록 하였으며 브랜드 관련한 설문 에 들어가서도 현재 거래하고 있는 산업제 공급 자의 브랜드에 대한 생각을 체크하도록 하였다.

표본특성을 살폐보면, 나이가 21세 30세 (39.2\%), 31세 40세(42.0\%), 41세 50세(11.3\%) 등으로 비교적 고르게 분포하는 것으로 나타났 으며 업종별로는 전자 $(33.5 \%)$, 전기 $(12.5 \%)$, 기제 $(22.2 \%)$, 화학 $(14.2 \%)$, 금속 $(9.0 \%)$ 등으로 분포되어 있다. 그리고 조직구매자의 직책은 사 원 $(50.9 \%)$, 대리급 $(21.7 \%)$, 과장급 $(14.6 \%)$, 차 장 혹은 부장급 $(11.8 \%)$, 본부장 혹은 이사급 $(0.9 \%)$ 순으로 타나났으며 거래기간에 있어서 는 1년 2년(39.6\%)과 3년 5년(37.7\%)이 가 장 많았으며 5 년 10 년 $(16.0 \%), 10$ 년 이상 $(5.7 \%)$ 도 일정 부분 있는 것으로 나타났다.

\section{3 측정변수들의 신뢰성 및 타당성 분석}

설문을 통해 각 변수들에 대한 측정항목의 구 성개념 타당성 및 내적 타당성은 기존 연구의 측정방식에 따라 지지되는 것으로 나타났다. 본 설문에 앞서 사전조사의 일환으로 전문가 그룹 조사를 통해 타당성의 검증을 진행하였으며 그 결과 타당성을 확보하고 있는 것으로 나타났다. 수집된 자료는 측정치들의 신뢰성과 타당성을
분석 한 후 공분산구조방정식분석 프로그램인 AMOS 5.0을 사용하여 구조방정식 모델을 분 석하고 각 연구가설콰 연구모형을 검증하였다.

신뢔성 분석결과를 살펴보면 모든 항목들의 Cronbach's a계수값이 0.899 0.963 사이로 내 적 일관성이 비교적 높은 것으로 나타났다. 일 반적으로 0.700 0.900 일 경우 설문의 신뢰성 이 보장된다고 볼 매 본 연구의 측정변수들에 대한 신뢰성은 높다고 볼 수 있다. 이에 앞서 다중상관제곱분석을 통해 지수가 0.3이하로 나 타난 브랜드 인지/연상(1개 항목), 기업성과(2 개 항목)에서 잠재번수 내의 일부 항목을 신뢰 성 확보를 위해 제거하였다.

본 연구에 포함된 이론변수들은 산업재 브랜 드 가치를 구성하는 오소 및 조직구매자와 공 급자간의 관계적 거래 성과요소에 대한 학계와 응용분야의 포괄적인 접근을 통해 구성하였으 며, 이론변수들 간의 인과관계 설정은 선행연구 를 기반으로 하였다. 측정모델을 통하여 전체적 으로 평가하기에 앞서 실증분석에 사용되는 측 정척도는 각 이론변수(잠재변수)별로 확증적 요인분석을 실시하여 타당성을 검증하였다. 연 구의 설문문항은 기존 문헌을 충분히 반영하였 으며 사전에 전문가의 의견을 반영하였다는 점 에서 내용타당성이 인정된다고 할 수 있다. 그 리고 본 연구의 확증적 요인분석, 상관관계분석 을 통해 구성개념 타당성 및 기준 타당성을 검 증하였다. 검증결과 이론변수(잠재요인)에 대한 확증적 요인분석을 통해 나온 요인 적재값이 모두 0.800 이상으로 iㅏ타나 모두 유의한 것으로 나타났으며 각 구성개념간의 상관관계에 대한 분석결과 역시 구성개념간의 통계적 유의성이 확보된 것으로 나타났다. 그리고 각 구성개념에 
대한 적합성 검증에 있어서도 적합기준을 충족 하는 것으로 나타나 본 연구의 이론변수들에 대한 타당성은 확보된 것으로 판단하였다.

이론변수를 중심으로 확증요인분석을 실시한
구조방정식 모형의 적합도 지수를 살펴보면 우 선 브랜드 가치 요인들에 대한 적합도 검증에 서는 브랜드 충성도에 영향을 미치는 영향요인 들(인지/연상, 지각품질, 지각가치, 관계만족,

〈표 1〉 측정변수들의 신뢰성 및 타당성

\begin{tabular}{|c|c|c|c|c|c|}
\hline 벤수 & 설문항목 & $\begin{array}{c}\text { 요인 } \\
\text { 적제값 }\end{array}$ & $\begin{array}{c}\text { 다중상관 } \\
\text { 제곱 }\end{array}$ & $\begin{array}{l}\text { 항목수 } \\
\text { (제개) }\end{array}$ & $\begin{array}{l}\text { 신홰정 } \\
\text { 계루 }\end{array}$ \\
\hline \multirow{8}{*}{$\begin{array}{c}\text { 브랜드 } \\
\text { 인지/연상 }\end{array}$} & 브랜드를 통한 제품 속성의 중요도 & 0.88 & 0.56 & \multirow{8}{*}{$\begin{array}{c}8 \\
(1)\end{array}$} & \multirow{8}{*}{0.958} \\
\hline & 브랜드를 통한 재품의 성격 & 0.91 & 0.62 & & \\
\hline & 브랜드를 통한 제품에 대한 기술수준 & 0.87 & 0.47 & & \\
\hline & 브랜드를 통한 공급자에 대한 명성 & 0.92 & 0.49 & & \\
\hline & 브랜드를 통한 공급자에 대한 신뢰 & 0.90 & 0.56 & & \\
\hline & 브랜드를 통한 공급자의 능력 & 0.88 & 0.85 & & \\
\hline & 브랜드를 통한 공급자의 긍정적 느낌 & 0.89 & 0.68 & & \\
\hline & 공급자 브랜드의 인지/연상 수준 & 0.74 & 0.54 & & \\
\hline \multirow{4}{*}{$\begin{array}{l}\text { 서비스 } \\
\text { 품질 }\end{array}$} & 제품 및 서비스 납기의 정확성 & 0.88 & 0.55 & \multirow{4}{*}{$\begin{array}{c}4 \\
(0)\end{array}$} & \multirow{4}{*}{0.899} \\
\hline & 제품 및 서비스 납기의 신속성 & 0.82 & 0,69 & & \\
\hline & 종업원 행동의 서비스 확신성 & 0.92 & 0.48 & & \\
\hline & 종업원의 정학한 고객욕구 파악능력 & 0.89 & 0.39 & & \\
\hline \multirow{6}{*}{$\begin{array}{l}\text { 지각된 } \\
\text { 가치 }\end{array}$} & 프리미엄 가격을 지불하려는 의도 & 0.85 & 0.34 & \multirow{6}{*}{$\begin{array}{c}6 \\
(0)\end{array}$} & \multirow{6}{*}{0.947} \\
\hline & 제품 및 서비스의 유연성 & 0.90 & 0.37 & & \\
\hline & 추가적인 혜택 및 자원 제공 & 0.88 & 0.41 & & \\
\hline & 제품에 대한 이해 & 0.90 & 0.44 & & \\
\hline & 제품가격예 대한 적절함 & 0.90 & 0.46 & & \\
\hline & 현재의 공급자와의 구매결정에 대한 판단 & 0.92 & 0.48 & & \\
\hline \multirow{4}{*}{$\begin{array}{l}\text { 관계 } \\
\text { 만족 }\end{array}$} & 공급자와의 구매결정의 현명함 퐌단 & 0.89 & 0.66 & \multirow{4}{*}{$\begin{array}{c}4 \\
(0)\end{array}$} & \multirow{4}{*}{0.915} \\
\hline & 공급자와의 구매결정에 따른 만족 & 0.90 & 0.68 & & \\
\hline & 공급자와의 구매결정에 따른 즐거움 & 0,90 & 0.69 & & \\
\hline & 공급자의 제품 및 서비스에 대한 추천 & 0.92 & 0.60 & & \\
\hline \multirow{4}{*}{$\begin{array}{l}\text { 브랜드 } \\
\text { 충성도 }\end{array}$} & 브랜드에 반복구매 의도 & 0.89 & 0.71 & \multirow{4}{*}{$\begin{array}{c}4 \\
(0)\end{array}$} & \multirow{4}{*}{0.913} \\
\hline & 공급자 브랜드의 지속적인 구매의도 & 0.90 & 0.73 & & \\
\hline & 지속적인 브랜드에 대한 열망 & 0.92 & 0.80 & & \\
\hline & 경쟁브랜드보다 높은 가격프리미엄 지불 & 0.87 & 0.84 & & \\
\hline
\end{tabular}


〈표 1〉 측정변수들의 신뢰성 및 타당성(계속)

\begin{tabular}{|c|c|c|c|c|c|}
\hline 변수 & 설문항목 & $\begin{array}{c}\text { 요인 } \\
\text { 적계값 }\end{array}$ & $\begin{array}{c}\text { 마중상관 } \\
\text { 제곱 }\end{array}$ & $\begin{array}{l}\text { 항목수 } \\
\text { (졔거) }\end{array}$ & a계수 \\
\hline \multirow{4}{*}{$\begin{array}{c}\text { 브랜드 } \\
\text { 전환비용 }\end{array}$} & 타사의 브랜드로 전환 시 소요 비용부담 & 0.94 & 0.61 & \multirow{4}{*}{$\begin{array}{c}4 \\
(0)\end{array}$} & \multirow{4}{*}{0.928} \\
\hline & 타사의 브랜드로 전환 시 느끼는 부담감 & 0.90 & 0.59 & & \\
\hline & 타사의 브랜드로 전환 시 시간의 부담 & 0.93 & 0.58 & & \\
\hline & 타사의 브랜드로 전환 시 느끼는 불편함 & 0.87 & 0.73 & & \\
\hline \multirow{6}{*}{$\begin{array}{c}\text { 브랜드 } \\
\text { 커뮤니티 }\end{array}$} & 온, 오프라인에서 업무시간외의 정보교환 & 0.83 & 0.69 & \multirow{6}{*}{$\begin{array}{c}6 \\
(0)\end{array}$} & \multirow{6}{*}{0.935} \\
\hline & 커뮤네티를 통한 의사반영 & 0.90 & 0.64 & & \\
\hline & 정보교환 외에 필요한 욕구충족 & 0.93 & 0.65 & & \\
\hline & 커뮤니티의 정서적 친밀감 & 0.89 & 0.72 & & \\
\hline & 타인에게 커뮤니티의 홍보 및 참여권유 & 0.90 & 0.74 & & \\
\hline & 앞으로 지속적인 커뮤니티 참여의향 & 0.79 & 0.77 & & \\
\hline \multirow{4}{*}{$\begin{array}{l}\text { 관계 } \\
\text { 몰입 }\end{array}$} & 지속적인 거래옥구 & 0.91 & 0.88 & \multirow{4}{*}{$\begin{array}{c}4 \\
(0)\end{array}$} & \multirow{4}{*}{0.921} \\
\hline & 긴밀한 관계유지 의도 & 0.91 & 0.80 & & \\
\hline & 지속적인 거래에 따른 손실감수 & 0.90 & 0.84 & & \\
\hline & 거래증진을 위한 투자의향 & 0.91 & 0.83 & & \\
\hline \multirow{8}{*}{$\begin{array}{l}\text { 기업 } \\
\text { 성과 }\end{array}$} & 거래 시 발생되는 비용의 절감 & 0.89 & 0.66 & \multirow{8}{*}{$\begin{array}{c}8 \\
(2)\end{array}$} & \multirow{8}{*}{0.963} \\
\hline & 주문 및 재고유지 비용의 절감 & 0.93 & 0.60 & & \\
\hline & 시세보다 낮은 가격으로 제품공급 & 0.86 & 0.62 & & \\
\hline & 매출성장에 기여정도 & 0.92 & 0.63 & & \\
\hline & 거래 단절시의 손해정도 & 0.92 & 0.69 & & \\
\hline & 제품 주문시의 배달의 신속함 & 0.88 & 0.70 & & \\
\hline & 제품 주문 시 정확한 납기 & 0.89 & 0.74 & & \\
\hline & 지사의 생산제품의 품질향상 & 0.88 & 0.64 & & \\
\hline \multirow{6}{*}{$\begin{array}{c}\text { 구매자 } \\
\text { 가치 }\end{array}$} & 제품 및 서비스의 수준의 적정한 가격 & 0.88 & 0.88 & \multirow{6}{*}{$\begin{array}{c}6 \\
(0)\end{array}$} & \multirow{6}{*}{0.947} \\
\hline & 가격에 비해 우수한 제품 및 서비스 제공 & 0.89 & 0.86 & & \\
\hline & 지불가격 이상의 우수한 가치졔공 & 0.89 & 0.81 & & \\
\hline & 뛰어난 전문적인 지식과 기술 & 0.88 & 0.79 & & \\
\hline & 믿을 수 있는 제품 및 서비스 제공 & 0.91 & 0.83 & & \\
\hline & 옥구의 파악 및 이해 능력 & 0.93 & 0.87 & & \\
\hline
\end{tabular}

전환비용, 커뮤니터)의 잠재변수(이론변수)에 대한 적합도 수치가 $x^{2}$ 값은 대부분 $40 \sim 52$
$(P=.000)$ 로 나타났으며 $\mathrm{GF}$ 는 $\quad 0.904 \sim 0.954$, $\mathrm{AGFI}$ 는 $0.901 \sim 0.945$ 로 나타났다. RMR은 
〈표 2〉 측정요인간의 상관관계

\begin{tabular}{|c|c|c|c|c|c|c|c|c|c|c|c|c|}
\hline \multirow{2}{*}{ 척도 } & \multirow{2}{*}{ 평균 } & 표준 & \multicolumn{10}{|c|}{ 구성개념간 상관관계(Inter-Construct Correlations) } \\
\hline & & 편차 & 1 & 2 & 3 & 4 & 5 & 6 & 7 & 8 & 9 & 10 \\
\hline 1. 인지/연상 & 3.42 & .63 & 1.00 & & & & & & & & & \\
\hline 2. 지각가치 & 3.39 & .85 & .23 & 1.00 & & & & & & & & \\
\hline 3. 서비스품질 & 3.45 & .65 & .32 & .25 & 1.00 & & & & & & & \\
\hline 4. 전환비용 & 3.37 & .68 & .35 & .41 & .36 & 1.00 & & & & & & \\
\hline 5. 관계만족 & 3.68 & .80 & .33 & .30 & .34 & .21 & 1.00 & & & & & \\
\hline 6. 커뮤니티 & 3.51 & .95 & .40 & .25 & .38 & .37 & .29 & 1.00 & & & & \\
\hline 7. 충성도 & 3.44 & .73 & .52 & .63 & .59 & .68 & .57 & .33 & 1.00 & & & \\
\hline 8. 관계몰입 & 3.58 & .78 & .56 & .58 & .53 & .50 & .54 & .59 & .62 & 1.00 & & \\
\hline 9. 기업성과 & 3.39 & .71 & .42 & .43 & .39 & .28 & .29 & .33 & .36 & .68 & 1.00 & \\
\hline 10.구매가치 & 3.81 & .77 & .26 & .28 & .23 & .20 & .24 & .29 & .34 & .51 & .47 & 1.00 \\
\hline
\end{tabular}

$0.022 \sim 0.023$ 을 보였으며 RMSEA는 0.023 0.045 로 나타났다. 그리고 $\mathrm{NFI}$ 와 $\mathrm{CFI}$ 는 각각 0.930 0.965와 0.938 0.961로 나타나 확증요인 분석을 위한 모형의 전반적인 적합도는 수용할 만할 수준으로 판단할 수 있다. 또한 브랜드 충 성도, 관계몰입. 그리고 기업성과에 대한 적합 도 검증에서는 적합도 수치가 $x^{2}$ 값은 대부분 52 62 $(P=.000)$ 으로 나타났으며, GFI는 0.933 0.967 , AGFI는 0.913 952로 나타났다. RMR은 $0.024 \sim 0.029$ 를 보였으며, RMSEA는 0.022 0.034 로 나타났다. 그리고 $\mathrm{NFI}$ 와 $\mathrm{CFI}$ 는 각각 $0.932 \sim 0.958$ 와 $0.934 \sim 0.945$ 로 나타나 확증요인 분석을 위한 모형의 전반적인 적합도는 수용할 만할 수준으로 판단할 수 있다.

본 연구의 잠재변수 및 측정변수들에 대한 타 당성 검사를 통해 종합적으로 살펴본 결과 확 증요인분석, 상관관계분석, 그리고 적합성 검증 의 결과는 모델 평가기준을 모두 상회하는 것 으로 나타나 이론변수(잠재요인)에 세부 측정
항목들이 충분하게 포함되어 있는 것을 확인되 어 타당성을 충분히 확보했다고 판단할 수 있다.

\section{4 구성모델의 경로계수분석}

실증분석은 AMOS 5.0의 구조방정식모델을 이용하여 분석하였다. 각각의 구성개넘에 대한 각 경로별 영향정도는 아래의 그림에 나와 있 는 경로계수의 값과 같으며 경로계수모형은 브 랜드태도 형성요인(브랜드 인지/연상, 브랜드 지각가치, 서비스 품질) 과 브랜드행동 형성요인 (브랜드 전환비용, 브랜드 관계만족, 브랜드 커 뮤니티), 브랜드 충성도, 관계몰입, 그리고 기업 성과 및 구매가치에 대한 가설적 관계를 제시 하고 있다. 모델평가와 가설검증을 위하여 구조 모델은 측정모델과 마찬가지로 항목지표(item indicator)를 척도로 사용하였다.

연구모델에 대한 경로분석을 통해 인과적 관 계를 살펴보기에 앞서 구성개념들의 구조적 관 
계에 대한 모델의 적합성을 검증해 볼 필요성 으로 인해 분석결과 가설적 모델의 전반적 적 합도는 만족스러운 수준(브랜드 커뮤니터를 제 외한 적합도)으로 나타났다. 우선 절대적합도에 서 $\chi^{2}$ 수치가 $273.12(P=.000)$ 로서 일반적으로 요구되는 수준인 $P$ 값 0.05 보다는 낮게 나타났 다. 이는 연구모형의 적합도가 조금 뗠어진다고 판단할 수도 있으나 $\chi^{2}$ 수치에 대하여 비판하 고 있는 주요 이유는 표본규모의 차이에 따라 지나치게 민감하게 변한다는 것이다. 결과적으 로 $x^{2}$ 에 의존하여 모형의 적합성을 판단하는 것은 충분치 않다고. 볼 수 있다. 절대 적합도에 서 GFI 수치는 절대적합도의 여러 수치 중에 가장 대표성을 나타내는 지표로 인식되고 있는 데 본 연구모형의 경우 GFI 수치는 0.951로 다 소 높은 수치를 나타냈다. 절대 적합도의 다른 지표인 RMR과 RMSEA의 경우 각각 0.030 와 0.056 으로 나타나 상당히 낮은 수준을 보여주었 다. 점증 적합도에서는 $\mathrm{AGFI}$ 의 경우 0.901, TLI는 0.934, NFI는 0.936으로서 수용수준을 보
였으며, 최적 적합도인 PNFI, PGFI, PCFI는 각각 $0.569,0.832$, 그리고 0.856 의 수치로 나타 나 양호한 수준으로 판단되었다. 이에 따라 본 연구의 구성모델에 대한 전반적인 적합도는 양 호한 것으로 팬단하였다.

이와 더불어 구성개념사이의 비표준화된 경로 추정치 모두가 $0.05,0.01$ 수준에서 유의한 것으 로 나타나 본 연구에서 제안한 가설 대부분이 통계적으로 유의한 것으로 나타났다(브랜드 충 성도의 브랜드 커뮤너티에 대한 가설은 제외). 가설검증의 걸과를 보면, 브랜드에 대한 인지/ 연상은 브랜드 충성도에 직접적인 정 $(+)$ 의 영 향을 미칠 것이다와 브랜드에 대한 지각된 가 치는 브랜드 충성도에 직접적인 정 $(+)$ 의 영향 을 미칠 것이다. 그리고 가설1-3의 브랜드에 대 한 지각된 서비스 품질은 브랜드 충성도에 직 접적인 정 $(+)$ 의 영향을 미칠 것이다는 브랜드 태도 형성요인에 대한 가설은 모두 통계적으로 유의한 것으로 나타낪다 $(P<.01)$. 브랜드 전환비 용은 브랜드 충성도배 긱접적인 정 $(+)$ 의 영향

〈표 3〉 구성모델에 대한 경로분석의 결가

\begin{tabular}{|r|l|l|l|c|c|c|}
\hline \multicolumn{2}{|c|}{ 인과경로 } & estimate & S.E. & C.R.(t값) & P \\
\hline 인지/연상 & $\Rightarrow$ & 브랜드충성도 & 0.33 & .089 & 3.70 & .000 \\
\hline 지각가치 & $\Rightarrow$ & 브랜드충성도 & 0.29 & .116 & 2.49 & .011 \\
\hline 서비스 품질 & $\Rightarrow$ & 브랜드충성도 & 0.35 & .137 & 2.56 & .010 \\
\hline 전환비용 & $\Rightarrow$ & 브랜드충성도 & 0.59 & .250 & 2.36 & .013 \\
\hline 관계만족 & $\Rightarrow$ & 브랜드충성도 & 0.26 & .033 & 2.91 & .003 \\
\hline 커뮤니티 & $\Rightarrow$ & 브랜드충성도 & 0.03 & .089 & 0.91 & .225 \\
\hline 브랜드충성도 & $\Rightarrow$ & 관계몰입 & 0.91 & .049 & 18.42 & .000 \\
\hline 관계몰입 & $\Rightarrow$ & 기업성과 & 0.63 & .034 & 18.36 & .000 \\
\hline 관계몰입 & $\Rightarrow$ & 구매가치 & 0.83 & .046 & 18.03 & .000 \\
\hline
\end{tabular}

참조) 모든 계수는 $P<0.05$ 수준에서 모두 통계적으로 유의(브랜드 커뮤니티 제외) 
을 미칠 것이다와 브랜드 관계만족은 브랜드 충성도에 직접적인 정 $(+)$ 의 영항을 미칠 것이 다는 가설들 또한 모두 유의한 영향을 미치는 것으로 나타났다 $(P(.01)$.

브롄드 충성도는 관계몰입에 직접적인 정 $(+)$ 의 영향을 미칠 것이다는 가설도 매우 유의한 영향을 미치는 것으로 나타났으며 관계몰입은 기업성과에 직접적인 정 $(+)$ 의 영항을 미칠 것
이다는 가설과 관계몰입은 구매자가치에 직접 적인 정 $(+)$ 의 영향을 미칠 것이다는 가설 모두 통계적으로 유의한 영향을 미치는 것으로 나타 났다( $P(.05)$. 그러나 브랜드 커뮤니티는 브랜드 충성도에 직접적인 정 $(+)$ 의 영향을 미칠 것이 다는 가설은 경로계수 및 유의수준이 정 $(+)$ 의 유의한 영향력을 보이지 않아 본 연구의 가설 에서 기각되었다.

\section{〈그림 1〉 구성모델의 경로계수 모형}

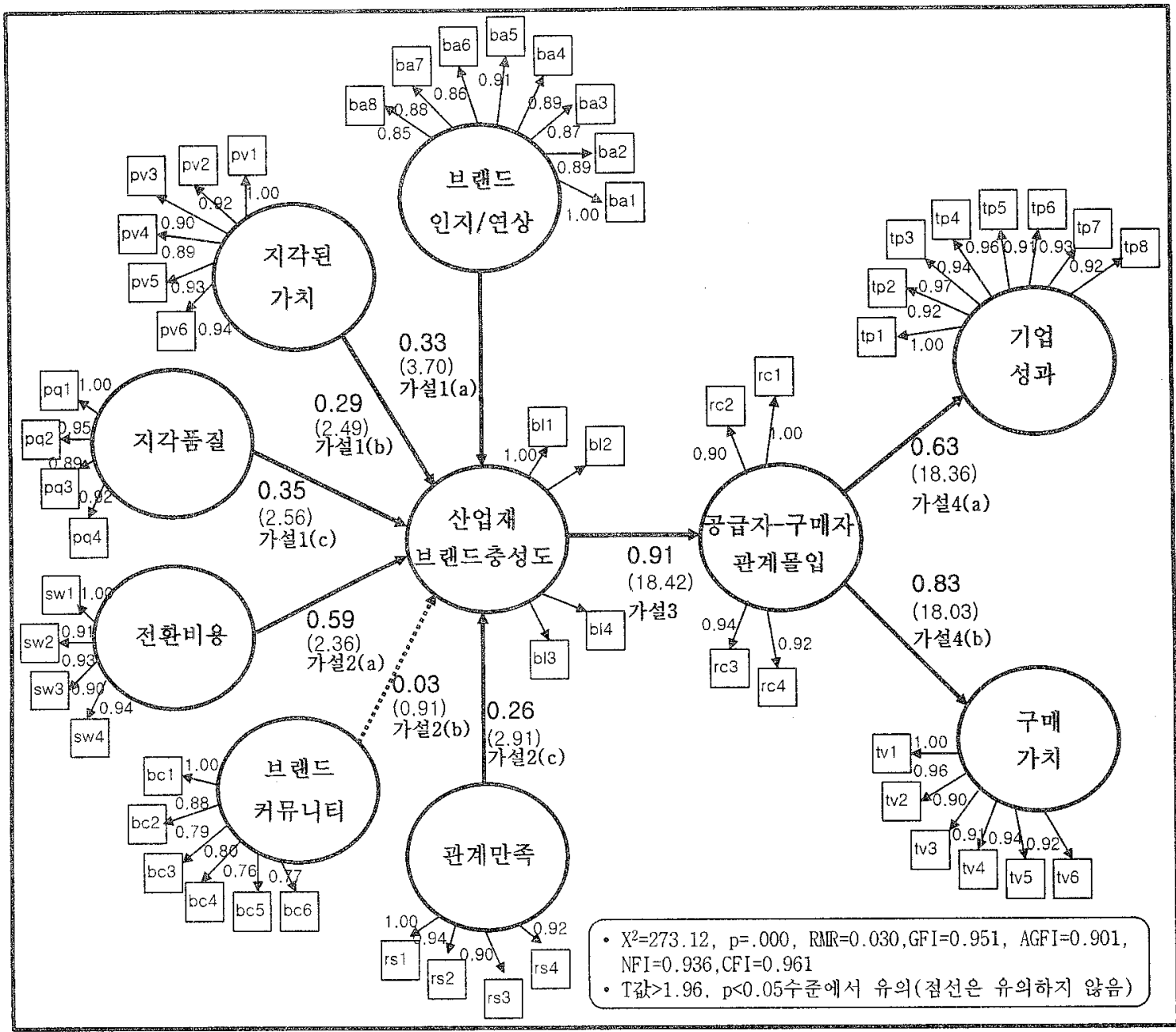

참조) 각 잠재변수별 첫 번째 측정항목의 값은 1.0 으로 고정한 것임. 
세부적으로 경로계수분석을 살펴보면, 인지/ 연상의 브랜드 충성도에 대한 영향은 경로분석 결과 경로계수값이 $0.33, \mathrm{C} . \mathrm{R}$.(t-value) 값이 3.70 으로 나타나 통계적 유의성 $(P=000)$ 을 확보한 것으로 판단된다. 그리고 지각가치의 브랜드충 성도에 대한 영향은 경로계수값이 0.29, C.R. ( $\mathrm{t}$-value) 값이 2.49로 나타나 역시 통계적 유의 성 $(P=.011)$ 을 확보한 것으로 판단된다. 서비스 품질의 브랜드충성도에 대한 영항은 경로계수 값과 ㄴㅏㅏㅄㅇㅣ 각각 $0.35,2.56$ 으로 나와 통계적으 로 유의한 $(P=.010)$ 것으로 나타났다. 그리고 전환비용의 브랜드충성도에 대한 영향은 각각 $0.59,2.36$ 으로 나타났고 관계만촉의 브랜드 충 셍도에 대한 영향은 $0.26,2.91$ 로 나타나 $P$ 값 이 0.05 수준에서 모두 유의한 것으로 나타났 다. 브랜드 충성도의 관계몰입에 대한 영향은 경로계수값과 $\mathrm{t}$ 값이 각각 $0.91,18.42$ 로 나타났 으며 관계몰입의 기업성과에 대한 영향은 0.63 , 18.36로 나왔으며 관계몰입의 구매가치에 대한 영향은 $0.83,18.03$ 으로 매우 높게 나타나 통계 적으로 매우 유의한 것으로 판단된다.

본 연구의 구조방정식을 이용한 실증분석에 대한 검증결과, 가설2-3을 제외하고는 가설 모 두가 통계적으로 유의하게 나타나 지지되고 있 는 것으로 실증분석을 통해 나타났다. 브랜드 커뮤니티의 브랜드 충성도에 대한 영향력이 통 계적으로 유의하게 나타나지 않은 것은 산업재 시장에서의 공급자 브랜드에 대한 커뮤니티는 브랜드 충성도를 높이는데 중요한 역할을 하지 않는 것을 의미한다고 볼 수 있다. 다시 말해 브랜드 커뮤니터의 브랜드 충성도에 대한 영향 력이 통계적으로 유의하게 나타나지 않은 것은 소비재 시장에서도 브랜드 충성도에 브랜드 커
뮤니티가 그. 영향력을 미치는 것이 비교적 최 근의 일이며, 특히 산업재 시장에서는 조직구매 자-공급자의 관계걱 특성 상 아직 브랜드 커뮤 니티가 정착되고 있지 않음을 생각해 볼 수 있 다. 본 연구는 가설검증의 분석결과, 브랜드태 도 형성요인(지각가치 제외) 및 브랜드행동 형 성요인(커뮤니티)이 통계적으로 가설을 지지하 는 것을 확인하였으며 브랜드 충성도, 관계몰 입, 그리고 기업성과 및 구매가치가 통계적으로 가설을 지지하는 것을 확인하였다.

\section{IV。결 론}

\section{1. 연구의 결과 및 의의}

본 연구의 실증분석결과를 통해 알 수 있듯이 산업재 시장에서도 브랜드에 대한 태도를 형성 하는 요인들 (브랜드 인지/연상, 서비스 품질)과 브랜드에 대한 행동을 형성하는 요인들(브랜드 전환비용, 브랜드 관계만족)은 브랜드 충성도를 증가시키며 공급자 구매자의 관계적 성과요인 들(관계몰입, 기업성과, 구매가치)에 중요한 영 항을 미치는 것으로 나타났다. 이는 산업재 시 장에서도 브랜드 충성도에 대한 정확한 측정과 그 효과에 대한 보다 세밀한 연구는 구매자와 공급자간의 장기적인 관계발전을 설정하는데 도움이 될 것으로 본다. 그러나 본 연구에서는 브랜드 커뮤너티의 브랜드 충성도에 대한 영향 력이 약하게 나타났는데 이것은 산업재의 특성 상 다양한 상황과 관계설정에 따라 다르게 해 석될 수 있음을 의미한다. 특히, 소비재 시장에 
서도 브랜드 충성도에 브랜드 커뮤니티가 그 영향력을 미치는 것이 비교적 최근의 일임을 감안한다면 산업재 시장에서는 서로간의 관계 적 특성 상 아직 브랜드 커뮤니티가 정착되어 있지 않고 있기 때문인 것으로 판단해 볼 수 있다.

본 연구의 가설검증에 대한 결과를 통해 보았 을 때 브랜드에 대한 인지/연상, 지각된 가치 및 지각된 서비스 품질이 브랜드 충성도에 통 계적으로 유의한 영향을 미치는 것으로 보았을 때 산업재 시장에서도 구매자-공급자의 거래관 계에서 구매자의 공급자 브랜드에 대한 인지/ 연상 수준 및 면상의 강도가 영향을 미치는 것 을 알 수 있다. 또한 공급업자의 브랜드에 대해 서 구매자가 느끼는 지각된 가치 및 서비스 품 질의 정도는 거래관계시 중요한 영향을 미치는 것을 알 수 있다. 이와 더불어 브랜드 전환비 용, 관계만족의 브랜드 충성도에 대한 직접적인 영향 또한 브랜드 충성도에 유의한 영향을 미 치는 것으로 나타났는데 이는 구매자-공급자의 거래관계 시 구매자가 느끼는 공급자 브랜드의 충성도에 전환비용과 관계만족이 중오한 영향 을 미치는 것으로 보여준다. 마지막으로 브랜드 충성도의 관계몰입에 대한 영향과 관계몰입의 기업성과 및 구매가치에 대한 영향이 모두 통 계적으로 상당히 높게 유의한 영향을 미치는 것으로 나타났는데 이는 브랜드 충성도가 산업 재 시장에서도 구매자-공급자 간의 거래 시 필 요한 관계적 몰입에 매우 중요한 영향을 미치 는 것을 알 수 있으며 또한 이러한 관계몰입은 최종적으로 산업재 시장에서의 기업성과 및 구 매가치를 증가 시키는 것을 알 수 있다. 공급자 가 자사의 브랜드 충성도를 높이기 위해서는
다양한 브랜드 자산 구성요인들에 대한 관심을 기울여야 함을 의미하며 브랜드 충성도가 높은 공급자의 브랜드는 구매자와의 관계몰입에 있 어서 커다란 장점을 갖고 있음을 의미한다.

본 연구를 통해 보았을 때 산업재 시장에서 조직구매자-공급자의 거래관계 시 공급자의 브 랜드 인지/연상, 지각된 서비스 품질, 브랜드 전환장벽, 브랜드 관계만족, 브랜드 충성도가 구매자와 공급자 간의 관계믈입과 구매가치를 통한 장기적 관계를 구축하는데 큰 영향을 미 치는 것을 알 수 있는데 조직구매자-공급자 간 의 거래 시 관계몰입을 유도하기 위해서는 브 랜드 가치를 구성하는 요인들이 매우 중요한 역할을 한다고 볼 수 있으며 더 나아가 이들 구성오인들 간의 구조적 관계를 파악하는 것이 더 중요하다고 볼 수 있다. 즉 공급자가 구매자 와의 장기적인 거래를 통한 관계의 질을 향상 시키고 관계몰입에 이르기 위해서는 자사의 브 랜드 가치를 높이기 위한 활동들이 우선적으로 구축해야 함을 의미한다고 볼 수 있다. 이를 통 해 봤을 때 본 연구의 보다 확장된 학문적 활 용방안을 살펴보면, 다음과 같다. 첫째, 산업재 시장에서 기존의 공급자-조직구매자의 단기적 거래에서 벗어나 관계적 거래로 전환하여 장기 적인 기업성과를 창출하는데 본 연구의 브랜드 가치요인들과 거래 성과요인들 간의 구조적 관 계에 대한 실증연구는 많은 학문적 활용방안을 제공한다고 볼 수 있다. 그동안의 단기간의 일 회적 거래 중심으로 비교적 새로운 고객을 확 보하고 일방적인 커뮤니케이션에 초점을 둔 것 과는 다르게 관계적 거래 하에서는 브랜드 충 성도에 의한 관계의 질 항상과 관계몰입을 통 해 장기간의 거래와 현재의 조직구매자를 확보 
하고 유지 및 회복하는데 있어서 거래비용을 줄이고 상호간 커뮤너케이션을 통해 원활한 상 호작용을 이루게 해줄 수 있기 때문이다. 둘째, 본 연구를 시작으로 앞으로 산업재 브랜드 가 치에 관한 보다 확장된 연구가 가능할 것으로 보인다. 예를 들어, 브랜드 특성요인(명성, 경쟁 력 등), 공급자 특성요인(신뢰, 기술 등), 구매 자 특성요인(제품지식, 경험 등) 등의 브랜드 신쾨 및 충성도 등에 미치는 영향에 관한 연구 들도 의미 있는 연구가 될 것으로 예상된다. 셋 째, 본 연구모델은 일반 소비자가 대상인 소비 재 시장에서도 충분하게 수용가능 할 것으로. 보이며 이에 대한 연구가 병행되어 산업재 시 장과 소비재 시장 간의 비교연구 또한 의미가 있을 것으로 보인다. 즉 소비재 시장에 대한 연 구 또한 매우 중요한 부분이라 할 수 있으며 이 부분에 대한 연구 또한 진행될 수 있을 것 으로 보인다.

\section{2 연구의 실무적 시사점}

산업재 구매자와 공급업자에게 그들의 거래관 계롤 평가하고 개선시키는데 산업재 시장에서 의 브랜드 충성도의 중요성 및 브랜드 충성도 를 높이기 위한 영향요인을 발견하고 이를 통 해 비추어 볼 때 유용하게 이용될 수 있는 산 업재 시장 내의 브랜드에 대한 자산관리의 개 념적 틀을 제공할 수 있으며 특히 산업재 조직 구매자들이 공급업자와의 관계를 보다 더 효과 적이고 성공적인 거래관계로 발전시카는 평가 기준이 될 수 있을 것으로 보인다.

산업재 시장에서 구매자-공급자 간의 관계에 서 몰입의 수준에 따라 기업성과 및 구매자의
가치가 큰 영항을 탆는다고 보았을 때 관계몰 입에 브랜드 충성도가 중요한 역할을 한다는 것은 향후의 공급업자의 브렌드에 대한 구매자 의 충성도를 높이는 작업이 반드시 수반되어야 함을 의미한다. 결곡, 거래관계에 영항을 미치 는 브랜드 충성도 및 선행변수들과 관계적 요 인들에 대한 분석은 산업재 시장에서의 경영 관리적 의미와 시사점을 통해 보다 더 효과적 인 구매자-공급자간의 거래를 향한 이론적, 실 무적 틀을 제공해 출 수 있다는 데서 본 연구 결과의 의의가 있다고 할 수 있다.

소비재 시장에서와 마찬가지로 산업재 시장에 서도 브랜드가 구매자 공급자와의 관계에서 중 요한 역할을 하는 것으로 나타났으며 산업재 시장에서도 브랜드에 대한 태도를 형성하는 오 인들(브랜드 인지/연상, 서비스 품질)과 브랜드 에 대한 행동을 헝성하는 요인들(브랜드 전환 비용, 브랜드 관계만족)은 브랜드 충성도를 증 가시키며 공급자-구매자의 관계몰입, 기업성과, 그리고 구매가치와 같은 관계적 성과에 중요한 영항을 미치는: 것으로 나타났다. 이는 산업재 시장에서도 거래관계 시 구매자의 공급자 브랜 드에 대한 인지도의 강도가 중요한 영향을 주 기 때문에 공급자는 자사의 브랜드 인지도를 높이기 위한 노력이 필요하다. 또한 공급업자의 브랜드에 대해서 구매자가 느끼는 지각된 가치 및 서비스 품질의 정도는 거래관계 시 중요한 요인이기 때둔에 구매자와의 거래 시 자사의 브랜드에 대한 가치와 서비스 품질을 높이기 위한 장기적인 마케팅 관리가 필요하다고 볼 수 있다. 그리고 브린드태도 형성요인과 마찬가 지로 조직구매자 공급자의 거래관계 시 구매자 가 느끼는 공급자 브랜드의 충성도에 전환비용 
과 관계만족이 중요한 요인인 것으로 나타남에 따라 공급자는 구매자와의 거래 시 관계적 만 족을 높이기 위한 노력과 전환비용을 더욱 더 높이는 활동이 필요하다. 마지막으로 브랜드 충 성도는 소비재 시장과 마찬가지로 산업재 시장 에서도 구매자-공급자 간의 장기적인 거래 시 관계적 몰입을 위해 매우 중요한 역할을 하는 것을 알 수 있다.

\section{3 연구의 한계점}

우선, 본 연구에서 나타났듯이 산업재 시장에 서 관계몰입이 성과에 영향을 준다면 과연 매 출이나 순이익 등에도 변화가 있는지를 분석할 필요가 있으나 현실적으로 비용수익 관련한 자 료들을 얻기가 힘들고 무엇보다 어느 특정기업 과의 거래에서 몰입과 같은 주관적 요인의 증 가가 기업의 매출이나 이익과 같은 객관적 수 치를 얼마나 증가시키는지를 찾아낸다는 것은 매우 어려워 결국 그 대안으로 성과에 대해 구 매 담당자들의 인식을 측정하여 분석할 수밖에 없었다. 그리고 본 연구가 산업재 조직구매자공급자 관계의 분석에 초점을 맞추었으나 실증 분석에서는 자료 수집상의 현실적 어려움 때문 에 구매기업으로부터 모은 자료만을 사용해왔 으며 보다 더 타당성 있는 연구가 되기 위해서 는 구매업자 뿐만 아니라 공급업자들로부터 얻 은 자료를 같이 분석에 사용해야 할 것이다. 이 와 더불어 실증분석에서 사용한 측정 척도와 관련하여 다소의 문제가 발생할 가능성을 배제 할 수 없다. 우선 본 연구에서 사용한 많은 척 도가 외국에서 개발된 것으로 한글로 번역하고 국내 산업재 시장 환경에 맞게 재조정한 것이
다. 따라서 원래 인용한 척도와 본 연구의 척도 사이의 그 의미가 완전하게 동일하다고 할 수 없는 한계가 있다. 그리고 본 연구의 이론적 구 성모델은 소비재 시장에서의 브랜드 관련연구 와 산업재 시장의 조직구매자-공급자의 거래 관련연구를 바탕으로 산업재 브랜드 관리의 틀 을 구성하여 실증적으로 검증하는데 그 의의가 있기는 하지만 기존연구의 배경을 중심으로 구 성모델을 만들었다고 해도 일부 변수간의 경로 에 있어 기존연구와는 상반되는 형태로 이론적 모델이 구성되어 있을 수도 있을 것이다.

〈논문 접수일: 2006. 10.14〉 〈게재 확정일: 2007. 04. 03〉

\section{참고문헌}

Aaker, D. A. (1996), "Measuring Brand Equity Across Products and Markets," California Management Review, 38 (1), 102-120.

Anderson, P. H. (2004), "Relationship marketing and brand involvement of professionals through web-enhanced brand communities: The case of Coloplast," Industrial Marketing Management, 34, 39-51.

Anderson, J. C. and A. Narus, (1990), “A Model of Distributor Firm and Manufacture Firm Working Partnerships," Joumal of Marketing, 54, 42-58.

Andreassen, T. W. and B. Lindestad(1998), "customer loyalty and complex services?" International Journal of Service Industry 
Management, 9(1), 7-23.

Bejou, D., B. Wray, and T. N. Ingram(1996), "Determinants of relationship quality: an artifitial neural network analysis?," Journal of Business Research, 36(2), 137-143.

Bendixen, M., Bukasa, K. A., and Abratt, R. (2004), "Brand equity in the businessto-business," Industrial Marketing Management, 33, 371-380.

Bloemer, J. M. M. and de Ruyter, K. (1998), "On the relationship between store image, store satisfaction and store loyalty?" $E u^{-}$ ropean Journal of Marketing, 32(5/6), 499513.

Cronin, J. J., Brady, M. K., and Hult, G. T. M. (2000), "Assessing the effects of quality, value, and customer satisfaction on consumer behavioral intentions in service environments?," Journal of Retailing, 76 (2), 193-218.

Doney, P. and Cannon, J. (1997), "An Examination of the Nature of Trust in Buyer-Seller Relationships," Journal of Marketing; 61, 35-61.

de Ruyter, K. and Wetzels, M. (2000), "Customer equity considerations in service recovery: a cross-industry perspective?," International Journal of Service Industry Management, 11(1), 91-108.

Dwyer, F. R., H. P. Schurr, and S. Oh(1987), "Developing Buyer-seller Relationships," Journal of Marketing, 58(1), 1-19.

Erdem, T. and J. Swait, (1998), "Brand equity as a signaling phenomenon?," Journal of Consumer PSychology, 7(2), 131-157.

Fornell, C., Johnson, M. D., Anderson, E. W., Cha, J., and Bryant, B. E. (1996), "The American customer satisfaction index: nature, purpose, and findings?" Journal of Marketing, 60(4), 7-18.

Ganesan, S. (1991), “Determinants of LongTerm Orientation in Buyer-Seller Relationships," Journal of Marketing; 58(1), 1-19.

Gronhaug, K. and Gilly, M. C. (1991), "A transaction cost approach to consumer dissatisfaction and complaint actions?," Journal of Economic Psychology, 12, 165183.

Grover, R. and V. Srinivasan (1992), "Evaluating the Multiple Effects of Retail Promotions or Brand Loyal and Brand Switching Segment," Journal of Marketing Research, 29(1), 76-89.

Han, Sang-Lin (1998), "Relational Factors Affecting the Business Relationships between Industrial Suppliers and Organizational Buyers," Korean Marketing Review, 13(1), 157-172.

Han, Sang-Lin (2003), "Antecedents of BuyerSupplier Relationships and Relational Performance in the Industrial Markets," Korean Journal of Channel Management, 8(1), 93-114.

Heskett, J. L., T. O. Jones, G. W. Loveman, W. E. Sasser, and L.A. Schlesinger(1994), "Putting the service-profit chain to work," 
Harvard Business Review, 72(2), 164-174. Jacoby, J.(1971), “A Model of Muti-Brand Loyaity," Journal of Advertising Research, 11(3), 25-31.

Jacoby, J., and Chestnut, R. W.(1978), Brand Loyalty: Measurement and Management, NY: John Wiley and Sons.

Jones, M. A., Mothersbaugh, D.L. and Beatty, S.E. (2000), "Switching barriers and repurchase intentions in services?," Journal of Retailing, 76(2), 259-274.

Kardes, F. R., G. Kalyanaram, M. Chandrashekaran, and R.J. Dornoff(1993), "Brand retrieval, consideration set composition, consumer choice, and the pioneering advantage," Journal of Consumer Research, 20(2), 62-75.

Kalwani, M. U., and N. Narayandas, (1995), "Long-Term Manufacturer -Supplier Relationships: Do They Pay Off for Supplier Firms?," Journal of Marketing, 59 (1), 116.

Keller, K. L., S. Heckler, and M. Houston, (1998), "The Effects of Brand Name Suggestiveness on Advertising Recall," Journal of Marketing, 62(1), 48-57.

Krishnan, H. S. (1996), "Characteristics of Memory Associations: A Consumer-based Brand Equity Perspective," International Journal of Research in Marketing, 13, $389-405$.

Krishnamurthi, L., Mazumdar, T. and S. P. Raj, (1992), "Asymmetric response to price in consumer brand choice and purchase quantity decisions?," Journal of Consumer Research, 19(3), 387-400.

Low, J. and Blois, K. (2002), "The evolution of generic brands in industrial markets: the challenges to owners of brand equity," Industrial Marketing Management, 31, 385-392.

Michell P., King J., and Reast, J. (2001), "Brand Values Related to Industrial Products," Industrial Marketing Management, 30, 415-425.

Mittal, V., Ross, W. T. Jr, and Baldasare, P. M. (1998), "The asymmetric impact of negative and positive attribute-level performance on overall satisfaction and repurchase intentions?," Journal of Marketing, 62(1), 33-47.

Morgan, R. M. and Hunt, S.D. (1994), "The commitment-trust theory of relationship marketing?," Journal of Marketing, 58(3), 20-38.

Muniz, A. and O'Guinn, T. (2001), "Brand Community," Journal of Consumer Research. 27(4), 412-432.

Oliver, R. L. (1993), "Cognitive, affective and attribute bases of the satisfaction response?," Journal of Consumer Research, 20(3), 418-430.

Parasuraman, A., Zeithaml, V. A., and Berry, L.L. (1994a), "Alternative scales for measuring service quality: a comparative assessment based on psychometric and 
diagnostic criteria?," Journal of Retailing, 70(3), 201-230.

Roberts, J. H. and Lattin, J. M. (1997), "Consideration: review of research and prospects for future insights?," Journal of Marketing Research, 34(3), 406-410.

Selnes, F. (1998), "Antecedents and consequences of trust and satisfaction in buyerseller relationships?," European Journal of Marketing, 32(3/4), 305-322.

Sharma, N. and Patterson, P. G. (2000), "Switching costs, alternative attractiveness and experience as moderators of relationship commitment in professional, consumer services?" International Journal of Service Industry Management, 11(5), 470-490.

Shocker, A. D., M. Ben-Akiva, B. Boccara, and P. Nedungadi(1991), "Consideration set influences on consumer decision-making and choice: issues, models and suggestions," Marketing Letters, 2(3), 181-197.

Schouten, J. W. and McAlexander, J. H. (1996), "Subcultures of Consumption: An Ethnography of the New Bikers," Journal of Consumer Research, 22(1), pp. 43-61.
Sinha, I. and W. DeSarbo (1998), "An integrated approach toward the spatial modeling of perceived customer value?," Journal of Niarketing Research, 35(2), 236-249.

Srinivasan, M. (1996), "New insights into switching behavior?," Journal of Marketing Research, 8(3), 27-33.

Taylor, S. A., K. Celuch, and S. Goodwin (2004), "The importance of brand equity to customer loyalty," Journal of Product \& Brand Mancigement, 13(4), 217-227.

Wells, B. P. and Stafford, M. R. (1995), "Service quality in insurance industry, Journal of Insurance Rgulation," 13(4), 462-477.

Yoo, B. H., Donthu, N., and S. Lee, (2000), "An Examination of Selected Marketing Mix Elements and Brand Equity," Journal of The Acadeny of Marketing Science, Spring, 28(2), 95-211.

Zeithaml, V. A., Berry, L.L. and Parasuraman, A. (1996), "The behavioral consequences of service quality?", Journal of Marketing, 60(2), 31-46. 


\title{
A Study on Industrial Brand Equity Affecting the Relational Performance between Industrial Buyers and Suppliers
}

\author{
Sang-Lin Han* \\ Hyung-Suk Sung**
}

\begin{abstract}
The recent development of industrial marketing explains the near absence of research on brand equity in business-to-business markets. With recent change, industrial companies have shifted from a production focus to a customer focus. Industrial brand concept is rapidly developing.

The basic purpose of this study is to investigate industrial brand equity affecting the result of business relationship between industrial buyers and suppliers. This research presented a comprehensive constructive model consisting of components of industrial brand equity, and then propose the research model base on prior researches and studies about relationships among components of industrial brand equity. Data were gathered from respondents who work in industrial buying center. For this study, Data were analyzed by SPSS 11.0 and AMOS 5.0.

The results of this research analysis were as fallow. Industrial brand loyalty was positively related with perceived value, perceived quality, brand awareness, relationship satisfaction, switching cost, relationship commitment. Also, Industrial corporate performance and purchasing value was positively related with brand loyalty and relationship commitment.
\end{abstract}

Key words: B-to-B relationships, industrial brand, brand loyalty, relationship performance

\footnotetext{
* Professor, School of Business, Hanyang University
}

** Lecturer, School of Business, Hanyang University 


\section{Introduction and Theoretical Background}

Industrial or business-to-business markets are often in the form of long-term business relationships. Many reasons exist why buyers enter into such relationships. While discrete transactions are governed by formal mechanisms such as written contracts, informal mechanisms (e.g., product brand) play an important role in relationships (Bendixen 2004).

The late development of industrial marketing explains the near absence of research on brand equity in business to business markets. With the recent changes, industrial companies have shifted from a production-focused to a customer-focused. The concept of industrial brand is becoming very important in the research area of business marketing. The basic purpose of this study is to investigate the industrial brand equity affecting the result of business relationship between industrial buyers and suppliers. This research presented a comprehensive constructive model consisting of components of industrial brand equity, and then proposed the research model based on prior researches and studies about relationships among components of industrial brand equity. Based on the previous researches and conceptual development of this research, total nine different research hypotheses were developed and a comprehensive model of industrial brand was proposed. Research hypotheses are as followis:

$\mathrm{H}$ la: Industrial brand awareness is positively related with industrial brand loyalty.

H 1b: Perceived value is positively related with industrial brand loyalty.

H 1c: Perceived service quality is positively related with industrial brand loyalty.

H 2a: Brand switching cost is positively related with industrial brand loyalty.

$\mathrm{H} 2 \mathrm{~b}$ : Relational satisfaction is positively related with industrial brand loyalty.

$\mathrm{H} 2 \mathrm{c}$ : Brand community is positively related with industrial brand loyalty.

H3: Industrial brand loyalty is positively related with relational commitment.

H 4a: Relational commitment is positively related with relational performance.

$\mathrm{H} 4 \mathrm{~b}$ : Relational commitment is positively related with purchasing value.

\section{Research Methodology}

The data used to test the research hypotheses were obtained by a stratified random sample. Data were gathered by a random-sample survey of organizational buyers of industrial products (for example electronics, chemicals, equipment). The questions were mainly answerable by seven-point likert scales. Of the 
230 questionnaires dispatched, The gross return of questionnaires was $n=230,18$ of which were either insufficiently completed. The final data used to test were 212 questionnaires. The response covered all geographical data and included a broad range of industries, sizes of firms, and respondent job titles, and no sources of non-response bias could be detected.

The validity of the measurement scales was also confirmed by evaluations provided by the participating company respondents and an independent advisory panel: samples provided recommendations throughout the primary, exploratory phases of the study. Construct validity may be threatened when factors in a proposed relationship are not linearly related along the whole continuum of the independent factor. Scatter plot analysis of preliminary data prior to the primary study indicated that confounding constructs and the levels of constructs are unlikely to compromise the validity of the study. The internal consistency method (using Cronbach coefficient alpha and SMC-Squared Multiple Correlation) was used to examine the reliability of the scales.

Inspection of the inter-constructs correlation matrix and Amos 5.0 s confirmatory factor analysis for all the items revealed no problems with convergent and discriminant validity. Prior to testing the research hypothesis, a confirmatory factor model was tested to assess the measurement and refine the measures. Confirmatory factor analysis was carried out to determine the construct validity of the measures. Items meant to measure the same construct were clustered together, suggesting that they measured the same conceptual space. The relationship between industrial brand

〈Table 1〉 Correlation table of the research constructs

\begin{tabular}{|c|c|c|c|c|c|c|c|c|c|c|c|c|}
\hline \multirow{2}{*}{ Factor } & \multirow{2}{*}{ Mean } & \multirow{2}{*}{ s.d. } & \multicolumn{10}{|c|}{ Inter-construct Correlations } \\
\hline & & & 1 & 2 & 3 & 4 & 5 & 6 & 7 & 8 & 9 & 10 \\
\hline 1. awareness & 3.42 & .63 & 1.00 & & & & & & & & & \\
\hline 2. perceived value & 3.39 & .85 & .23 & 1.00 & & & & & & & & \\
\hline 3. service quality & 3.45 & .65 & .32 & .25 & 1.00 & & & & & & & \\
\hline 4. switching cost & 3.37 & .68 & .35 & .41 & .36 & 1.00 & & & & & & \\
\hline 5. satisfaction & 3.68 & .80 & .33 & .30 & .34 & .21 & 1.00 & & & & & \\
\hline 6. community & 3.51 & .95 & .40 & .25 & .38 & .37 & .29 & 1.00 & & & & \\
\hline 7. loyalty & 3.44 & .73 & .52 & .63 & .59 & .68 & .57 & .33 & 1.00 & & & \\
\hline 8. commitment & 3.58 & .78 & .56 & .58 & .53 & .50 & .54 & .59 & .62 & 1.00 & & \\
\hline 9. performance & 3.39 & .71 & .42 & .43 & .39 & .28 & .29 & .33 & .36 & .68 & 1.00 & \\
\hline 10. purchasing value & 3.81 & .77 & .26 & .28 & .23 & .20 & .24 & .29 & .34 & .51 & .47 & 1.00 \\
\hline
\end{tabular}


values and relationship performance was then tested using structural equation modeling and a chi-square difference test. The brand value constructs commenced with each other indicators and were stayed significant and reduced as shown in the 〈Table 1). The following tale shows the correlation table of the research constructs.

\section{Results}

The proposed research model and research hypotheses were tested by using structural equation model and the following table and figure show the results of the hypotheses testing and model estimation.

The proposed research model and research hypotheses were tested by using the data collected from the industrial markets. The resulting goodness-of-fit statistics were a RMR of 0.03, GFI and AGFI greater than 0.90, and a chi-square with $270.00(p=0.00)$. The indicators of each construct were very good measures of variables and had high convergent validity as evidenced by the reliability, with a more than 0.90. Some items were deleted, leaving those that reflected the cognitive dimension of importance rather than the original dimension. The indicators were very good measures and hat convergent validity as evidenced by the reliability of 0.90 . These results for all constructs indicate the measurement fits the sample data well and is adequate for use (Anderson and Gerbing, 1988). Managerial implications of the results of the study were discussed and the limitations of the research were also explained.

The results of this research were as fallow.

〈Table 2〉 Estimation results of the hypotheses testing*

\begin{tabular}{|r|r|l|c|c|c|c|}
\hline \multicolumn{2}{|c|}{ Causal Path } & estimate & S.E. & C.R.(t-value) & $p$ \\
\hline awareness & $\Rightarrow$ & brand loyalty & 0.33 & .089 & 3.70 & .000 \\
\hline perceive value & $\Rightarrow$ & brand loyalty & 0.29 & .116 & 2.49 & .011 \\
\hline service quality & $\Rightarrow$ & brand loyalty & 0.35 & .137 & 2.56 & .010 \\
\hline switching cost & $\Rightarrow$ & brand loyalty & 0.59 & .250 & 2.36 & .013 \\
\hline satisfaction & $\Rightarrow$ & brand loyalty & 0.26 & .033 & 2.91 & .003 \\
\hline community & $\Rightarrow$ & brand loyalty & 0.03 & .089 & 0.91 & .225 \\
\hline brand loyalty & $\Rightarrow$ & commitment & 0.91 & .049 & 18.42 & .000 \\
\hline commitment & $\Rightarrow$ & performance & 0.63 & .034 & 18.36 & .000 \\
\hline commitment & $\Rightarrow$ & purchasing value & 0.83 & .046 & 18.03 & .000 \\
\hline
\end{tabular}

* All coefficients are statistically significant at $p=0.05$ (except brand community) 
Industrial brand loyalty was positively related with perceived value, perceived quality, brand awareness, relationship satisfaction, switching cost, and relationship commitment. Also, corporate relational performance and purchasing value were positively related with brand loyalty and relationship commitment.

One of the important results of the empirical tests is that our focal construct plays a critical role in a B-to-B relationship. The results discussed here represent a first step towards a better understanding of the industrial brand construct in customer-supplier relationships. A. two-sided research method would be useful in assessing the impact of brand and other critical variables in the business-to-business market relationships.

〈Figure 1〉 Results of the analysis of the research model

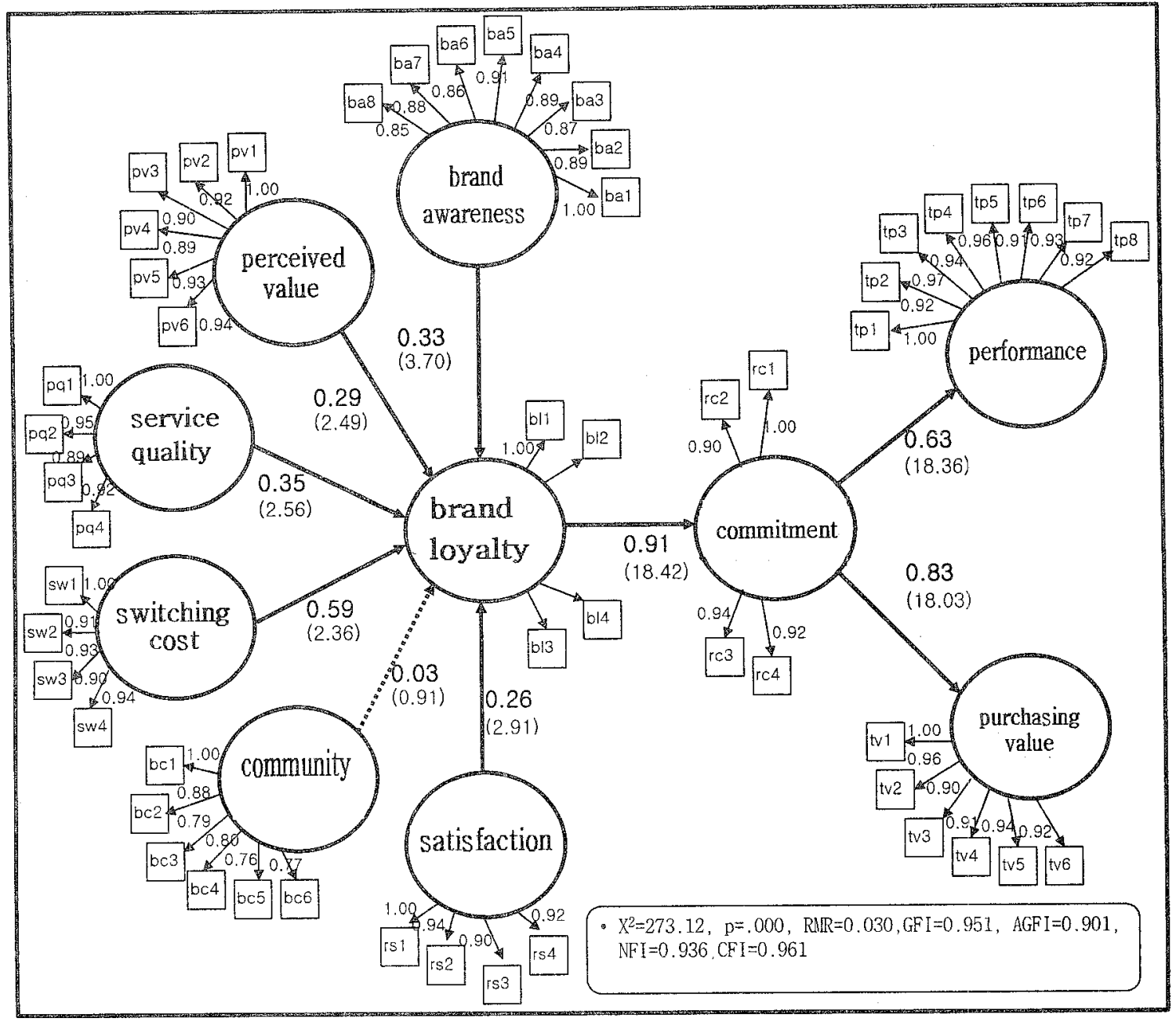




\section{References}

Aaker, D. A. (1996), "Measuring Brand Equity Across Products and Markets," California Management Review, 38 (1), 102-120.

Anderson, P. H. (2004), "Relationship marketing and brand involvement of professionals through web-enhanced brand communities: The case of Coloplast," Industrial Marketing Management, 34, 39-51.

Anderson, J. C. and A. Narus, (1990), "A Model of Distributor Firm and Manufacture Firm Working Partnerships," Journal of Marketing, 54, 42-58.

Andreassen, T. W. and B. Lindestad(1998), "customer loyalty and complex services?." International Journal of Service Industry Management, 9(1), 7-23.

Bejou, D., B. Wray, and T. N. Ingram(1996), "Determinants of relationship quality: an artifitial neural network analysis?," Journal of Business Research, 36(2), 137-143.

Bendixen, M., Bukasa, K. A., and Abratt, R. (2004), "Brand equity in the businessto-business," Industrial Marketing Management, 33, 371-380.

Bloemer, J. M. M. and de Ruyter, K. (1998). "On the relationship between store image, store satisfaction and store loyalty?," European Journal of Marketing, 32(5/6), 499513.

Cronin, J. J., Brady, M. K., and Hult, G. T .M.
(2000), "Assessing the effects of quality, value, and customer satisfaction on consumer behaviorall intentions in service environments?" Journal of Retailing, 76 (2), 193-218.

Doney, P. and Carnon, J. (1997), "An Examination of the Nature of Trust in BuyerSeller Relationships," Journal of Marketing, 61, 35-61.

de Ruyter, K. and Wetzels, M. (2000), "Customer equity considerations in service recovery: a cross-industry perspective?," International Journal of Service Industry Management, 11(1), 91-108.

Dwyer, F. R., H. P. Schurr, and S. Oh(1987), "Developing Buyer-seller Relationships," Journal of Marketing, 58(1), 1-19.

Erdem, T. and J. Swait, (1998), "Brand equity as a signaling phenomenon?" Journal of Consumer Psychology, 7(2), 131-157.

Fornell, C., Johnson, M. D., Anderson, E. W., Cha, J., and Bryant, B. E. (1996), "The American customer satisfaction index: nature, purpose, and findings?," Journal of Marketing, 60(4), 7-18.

Ganesan, S. (1994), "Determinants of LongTerm Orientation in Buyer-Seller Relationships," Journal of Marketing, 58(1), 1-19.

Gronhaug, K. and Gilly, M. C. (1991), “A transaction cost approach to consumer dissatisfaction and complaint actions?," Journal of Economic Psychology, 12, 165- 183.

Grover, R. and V. Srinivasan (1992), "Evalua- 
ting the Multiple Effects of Retail Promotions on Brand Loyal and Brand Switching Segment," Journal of Marketing Research, 29(1), 76-89.

Han, Sang-Lin (1998), "Relational Factors Affecting the Business Relationships between Industrial Suppliers and Organizational Buyers," Korean Marketing Review, 13(1), $157-172$.

Han, Sang-Lin (2003), "Antecedents of BuyerSupplier Relationships and Relational Performance in the Industrial Markets," Korean Joumal of Channel Management, 8(1), 93-114.

Heskett, J. L., T. O. Jones, G. W. Loveman, W. E. Sasser, and L.A. Schlesinger(1994), "Putting the service-profit chain to work," Harvard Business Review, 72(2), 164-174. Jacoby, J.(1971), "A Model of Muti-Brand Loyalty," Joumal of Advertising Research, $11(3), 25-31$.

Jacoby, J., and Chestnut, R. W.(1978), Brand Loyalty: Measurement and Management, NY: John Wiley and Sons.

Jones, M. A., Mothersbaugh, D. L. and Beatty, S. E. (2000), "Switching barriers and repurchase intentions in services?," Joumal of Retailing, 76(2), 259-274.

Kardes, F. R., G. Kalyanaram, M. Chandrashekaran, and R. J. Dornoff(1993), "Brand retrieval, consideration set composition, consumer choice, and the pioneering advantage," Journal of Consumer Research,
$20(2), 62-75$.

Kalwani, M. U., and N. Narayandas (1995), "Long-Term Manufacturer -Supplier Relationships: Do They Pay Off for Supplier Firms?," Journal of Marketing, 59 (1), 116.

Keller, K. L., S. Heckler, and M. Houston, (1998), "The Effects of Brand Name Suggestiveness on Advertising Recall," Joumal of Marketing, 62(1), 48-57.

Krishnan, H. S. (1996), "Characteristics of Memory Associations: A Consumer-based Brand Equity Perspective," International Journal of Research in Marketing, 13, 389-405.

Krishnamurthi, L., Mazumdar, T. and S. P. Raj, (1992), "Asymmetric response to price in consumer brand choice and purchase quantity decisions?," Journal of Consumer Research, 19(3), 387-400.

Low, J. and Blois, K. (2002), "The evolution of generic brands in industrial markets: the challenges to owners of brand equity," Industrial Marketing Management, 31, 385-392.

Michell P., King J. and Reast, J. (2001), "Brand Values Related to Industrial Pro" ducts," Industrial Marketing Management, 30, 415-425.

Mittal, V., Ross, W. T. Jr and Baldasare, P. M. (1998), "The asymmetric impact of negative and positive attribute-level performance on overall satisfaction and repurchase 
intentions?," Journal of Marketing, 62(1), 33-47.

Morgan, R. M. and Hunt, S. D. (1994), "The commitment-trust theory of relationship marketing?" Journal of Marketing, 58(3), 20-38.

Muniz, A. and O'Guinn, T. (2001), "Brand Community," Joumal of Consumer Research, $27(4), 412-432$.

Oliver, R. L. (1993), Cognitive, "affective and attribute bases of the satisfaction response?", Journal of Consumer Research, 20(3), 418430.

Parasuraman, A., Zeithaml, V. A, and Berry, L.L. (1994a), "Alternative scales for measuring service quality: a comparative assessment based on psychometric and diagnostic criteria?," Journal of Retailing, 70(3), 201-230.

Roberts, J. H. and Lattin. J. M. (1997), "Consideration: review of research and prospects for future insights?" Joumal of Marketing Research, 34(3), 406-410.

Selnes, F. (1998), "Antecedents and conse-quences of trust and satisfaction in buyerseller relationships?," European Joumal of Marketing, 32(3/4), 305-322.

Sharma, N. and Patterson, P. G. (2000), "Switching costs, alternative attractiveness and experience as moderators of relationship commitment in professional, consumer services?, International Journal of Service Industry Management, 11(5), 470-490.
Shocker, A. D., M. Ben-Akiva, B. Boccara, and P. Nedungadi(1991), "Consideration set influences on consumer decision-making and choice: issues, models and suggestions," Marketing Letiers, 2(3), 181-197.

Schouten, J. W. and McAlexander, J. H. (1996), "Subcultures of Consumption: An Ethnography of the New Bikers," Journal of Consumer Research, 22(1), pp. 43-61.

Sinha, I. and W. DeSarbo (1998), "An integrated approach toward the spatial modeling of perceived customer value?" Journal of Marketing Research, 35(2), 236-249.

Srinivasan, M. (1996), "New insights into switching behavior?," Journal of Marketing Research, 8(3), 27-33.

Taylor, S. A., K. Celuch, and S. Goodwin, (2004), "The importance of brand equity to customer loyalty," Journal of Product \& Brand Management, 13(4), 217-227.

Wells, B. P. and Stafford, M. R. (1995), "Service quality in insurance industry," Journal of Insurance Rgulation, 13(4), 462477.

Yoo, B. H., Donthu, $N_{.}$and S. Lee, (2000), "An Examination of Selected Marketing Mix Elements and Brand Equity," Journal of The Acadeny of Marketing Science, Spring, 28(2), 195-211.

Zeithaml, V. A., Berry, L. L. and Parasuraman, A. (1996), "The behavioral consequences of service quality?," Journal of Marketing, $60(2), 31-46$. 